Historic, Archive Document

Do not assume content reflects current scientific knowledge, policies, or practices. 

62.61

\section{AMAWALIK}

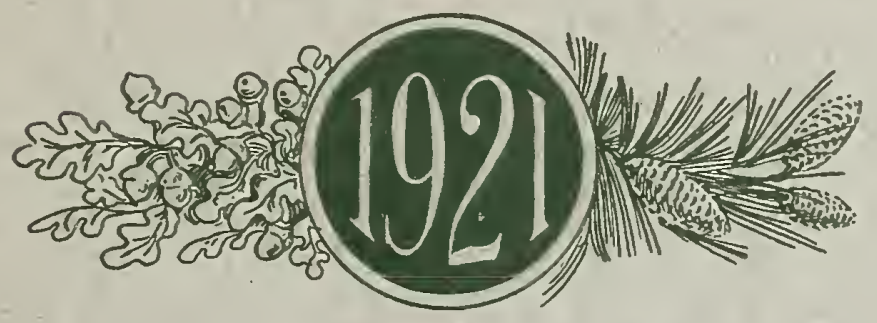

\section{SPECIMEN EVERGREEN AND DECIDUOUS TREES}







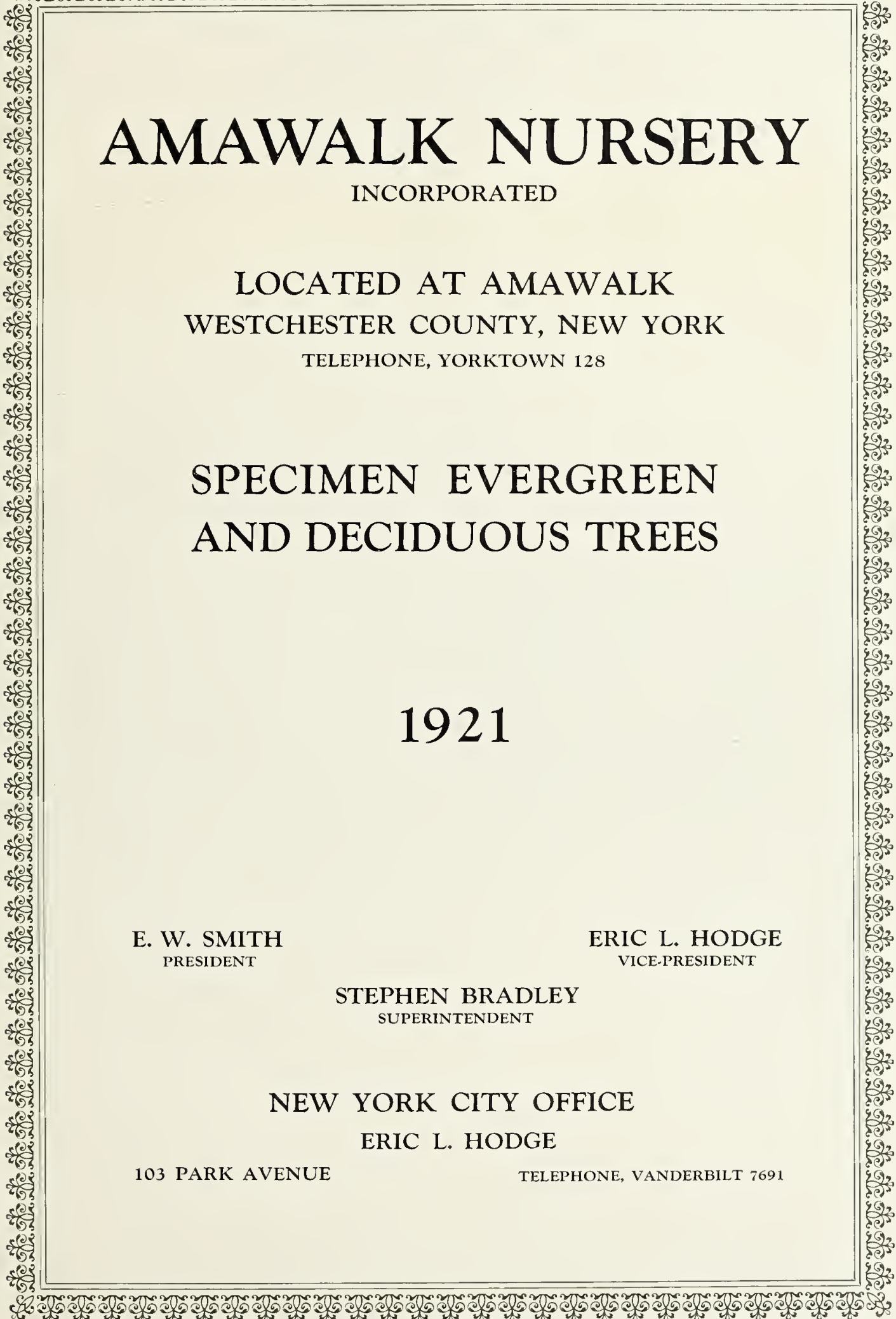

cécher 


\section{Table of Contents}

Instructions for reaching Nursery . . . . Frontispiece

Map . . . . . . . . . . . . Frontispiece

Introduction . . . . . . . . . . . . . 3

Deciduous Trees . . . . . . . . . . . 6-14

Evergreens . . . . . . . . . . . . . 15-21

Prices . . . . . . . . . . . . . . . 26

Deliveries . . . . . . . . . . . . 26

Shipping . . . . . . . . . . . . . 26

Guarantee • . . . . . . . . . . . 26

Sizes and Prices of Trees . . . . . . . . . 27-37

Instructions for Planting . . . . . . . . . 38-40 

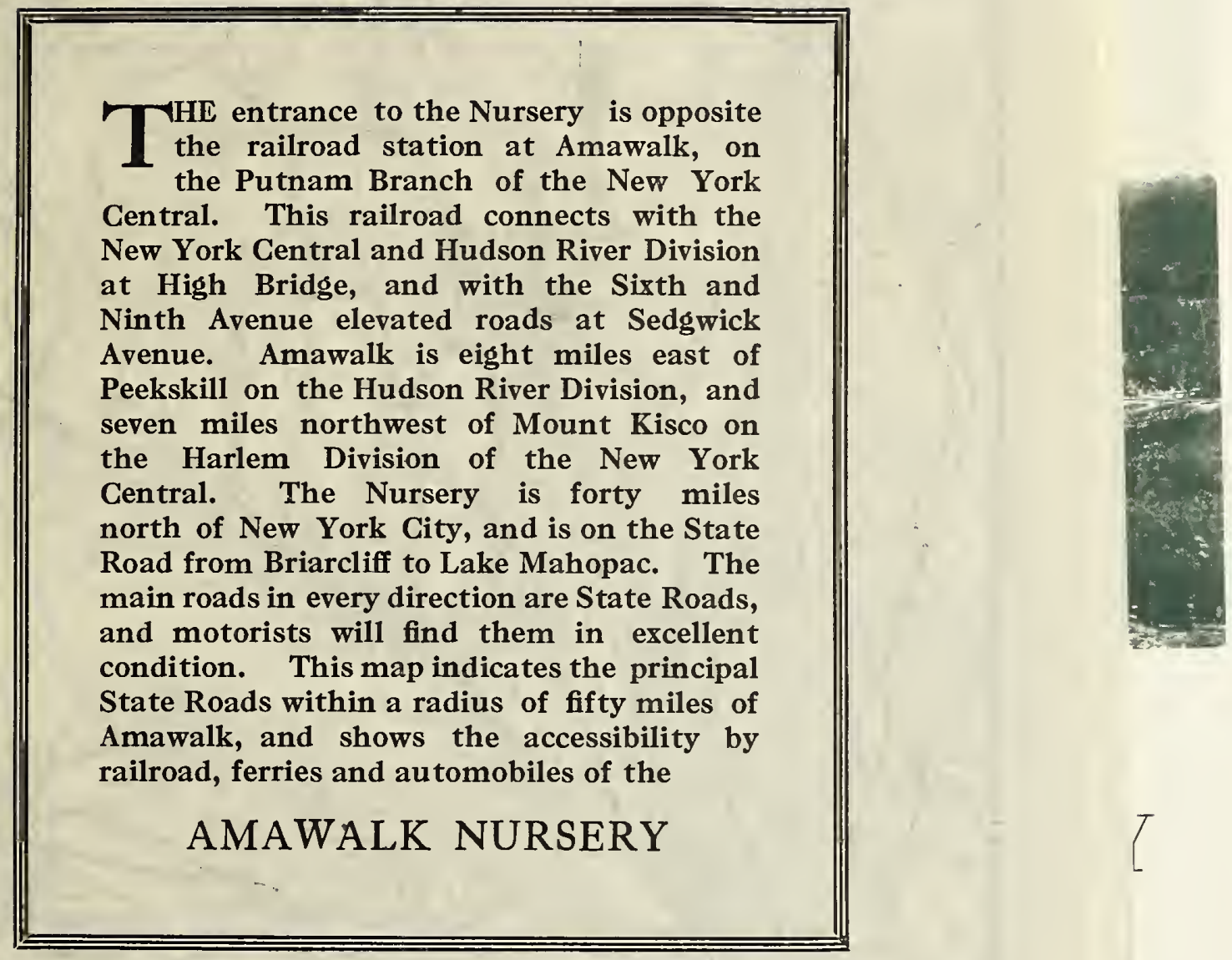

or the

- By

it will

anted,

$r$.

alk is

York

Island

art of

n im-

iprises

e hills

ie low

es and 

7 HE entrance to the Nursery is opposite the railroad station at Amawalk, on the Putnam Branch of the New York Central. This railroad connects with the New York Central and Hudson River Division at High Bridge, and with the Sixth and Ninth Avenue elevated roads at Sedgwick Avenue. Amawalk is eight miles east of Peekskill on the Hudson River Division, and seven miles northwest of Mount Kisco on the Harlem Division of the New York Central. The Nursery is forty miles north of New York City, and is on the State Road from Briarcliff to Lake Mahopac. The main roads in every direction are State Roads, and motorists will find them in excellent condition. This map indicates the principal State Roads within a radius of fifty miles of Amawalk, and shows the accessibility by railroad, ferries and automobiles of the

\section{AMAWALK NURSERY}




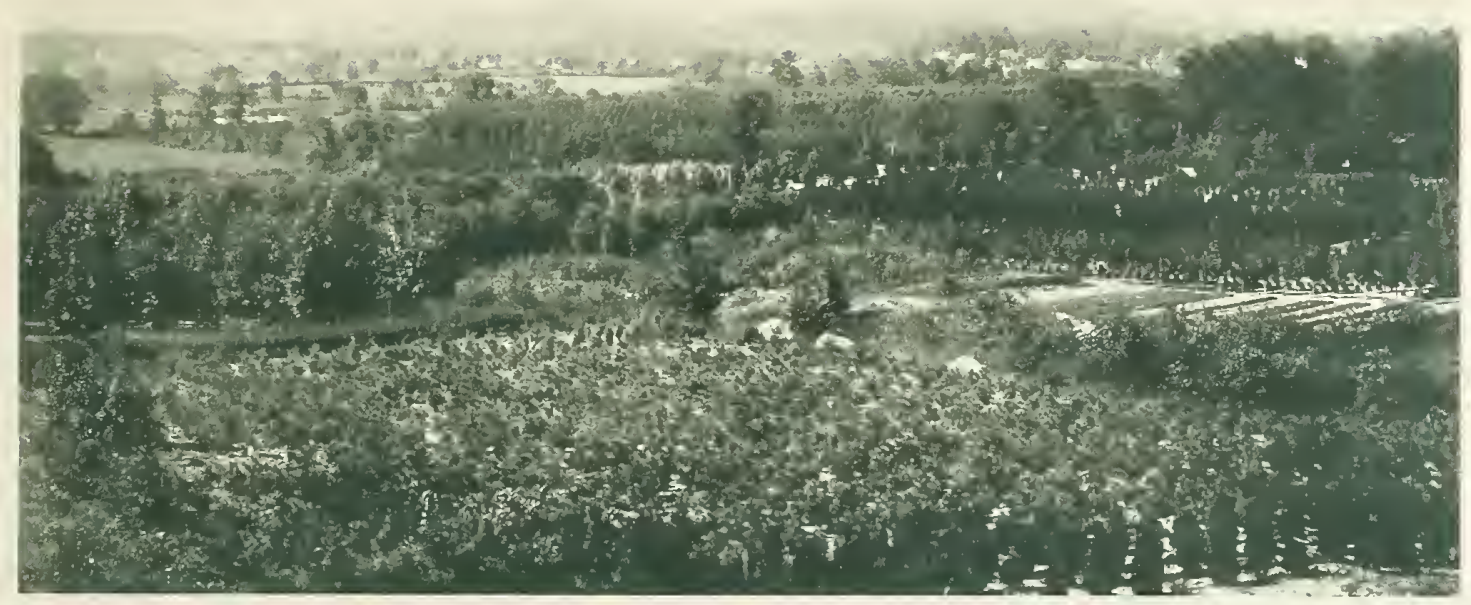

Partial view of Amawalk Nursery, taken from the hills.

\section{THE AMAWALK NURSERY Introduction}

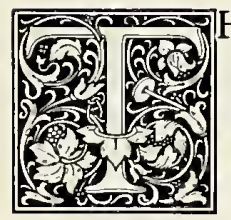

HE Amawalk Nursery was established eighteen years ago for the purpose of producing specimen deciduous and evergreen trees. By specimen trees we mean trees that are practically perfect; that will be useful and ornamental from the beginning; and, properly planted, will develop rapidly and increase in beauty as they grow older.

The location for our Nursery was most carefully selected. Amawalk is situated among the hills of Westchester County, thirty miles north of New York City. We are in the midst of the estate country located between Long Island Sound and the Hudson River. There are no manufacturing towns in this part of the country, and our air is consequently free from smoke and gasses-an important factor in the development of evergreens. The Amawalk Nursery comprises nearly 300 acres of the most fertile land in this part of the country. On the hills in our Nursery we have light, dry soils and exposed situations, and in the low lands, rich, heavy ground and sheltered locations. Owing to these exposures and 
soils we are enabled to grow each kind of tree under the conditions most favorable to its development. As our winters are unusually severe, we are limited to growing only those varieties which we have proved to be absolutely hardy. It is our practice to discontinue growing any variety of tree which will not stand our most severe winters, such as the London Plane (Platanus Orientalis) and numerous varieties of fancy evergreens. We are naturally anxious to include for the benefit of our customers, as many varieties as possible, but our practice always has been never to offer for sale any tree that we are not convinced will thrive and reach its full development when transplanted to a park or private estate. Our severe winter climate, however, has enabled us to develop trees of greater strength and vitality than are usually obtainable in a milder climate.

The preliminary care of the ground before the young trees are planted is extremely important. At Amawalk the ground is thoroughly prepared by deep ploughing and fertilization, and after the trees are planted they are constantly cultivated from May until September. This stirring up of the ground not only prevents the growth of weeds, but greatly increases the activity of the young roots. Our trees are planted unusually far apart, and as they grow are frequently root pruned and transplanted. Experts prune off imperfect or badly formed branches, and otherwise correct any inclination toward crookedness or ugliness. Thus cared for, our trees develop rapidly and experience the minimum setback after transplanting.

In 1903 the first small trees were planted at Amawalk, the finest stock obtainable. This high standard has been consistently maintained ever since. We never plant or keep a tree in our Nursery that is not perfect in every respect, as poor, unhealthy trees will never develop into fine, large specimens.

In 1909 the first Amawalk trees were offered for sale. Each year our trees are developing into finer and larger specimens, receiving our constant care and attention preparatory for their final transplanting. In this catalogue for 1921 every tree listed has been growing in our Nursery for from five to eighteen years.

We are always pleased to have our customers visit the Nursery and select by tagging their own trees. When this is not convenient, we make our best selection for them.

No order is dug until just before the trees are to leave the Nursery. If the trees are to be delivered by truck, they are dug in the morning, loaded on the truck in the afternoon, and delivered as early as possible the next morning. When the order is to be shipped by freight, the trees are not dug until the freight car is in on our siding. The greatest care is taken in the digging and handling of our trees, so as not to injure either the root system or the branches. Our most experienced men are in charge of the digging, the balling and the loading of the trees. In loading a truck, 
the number of trees, sizes and varieties are considered in order to obtain a well balanced load and insure the delivery of all the trees in good condition. Whenever we have several small orders to be delivered by truck in one neighborhood, we make the deliveries in one load, thereby reducing the delivery charge for our customers. In loading a freight car, the trees are placed in the car as soon as they are dug; the roots are then covered with straw and soaked with water. This is to prevent the roots from drying out. The trees are placed in the car in such a way as to facilitate the unloading, and we send, whenever desired, instructions for the unloading of each car.

Owing to our location on the Putnam branch of the New York Central Railroad we are able to obtain the large double-door, end-door automobile freight cars that come to New York City from the West. These cars are routed back empty and are easy for us to obtain. Another advantage of our location on the Putnam Railroad is that our freight shipments to the North, South, East and West do not have to be routed through New York City. Our shipments to the West make Albany the second day after leaving Amawalk.

We send to each customer upon request a booklet containing full information and illustrations on the planting and after care of trees. For abbreviated instructions in planting see pages 38 to 40 of this catalogue.

We have had a great deal of experience in the proper selection of trees to be planted, which includes the consideration of the soil conditions and exposure to winds and sunlight, and their effect upon the different varieties. This experience we place at the command of our customers.

Through a method of inspection of all trees planted within calling distance of our Nursery, we are in touch with the condition of each tree we send out and give advice in regard to its care. These inspections are made periodically, and a record is kept in our office. To those customers who live too far from our Nursery to get the benefit of this service we give our best advice by letter, and endeavor to have a representative inspect their trees at least once or twice a year.

It is our desire to reach the point where every tree that we send out not only lives, but thrives, and we are anxious to co-operate with our customers to this end, and to obtain for them at an early date the full beauty and development of their trees.

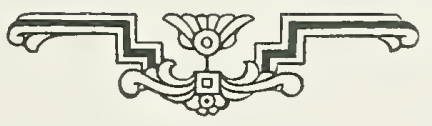




\section{THE FOLLOWING PHOTOGRAPHS TAKEN AT THE AMAWALK NURSERY}

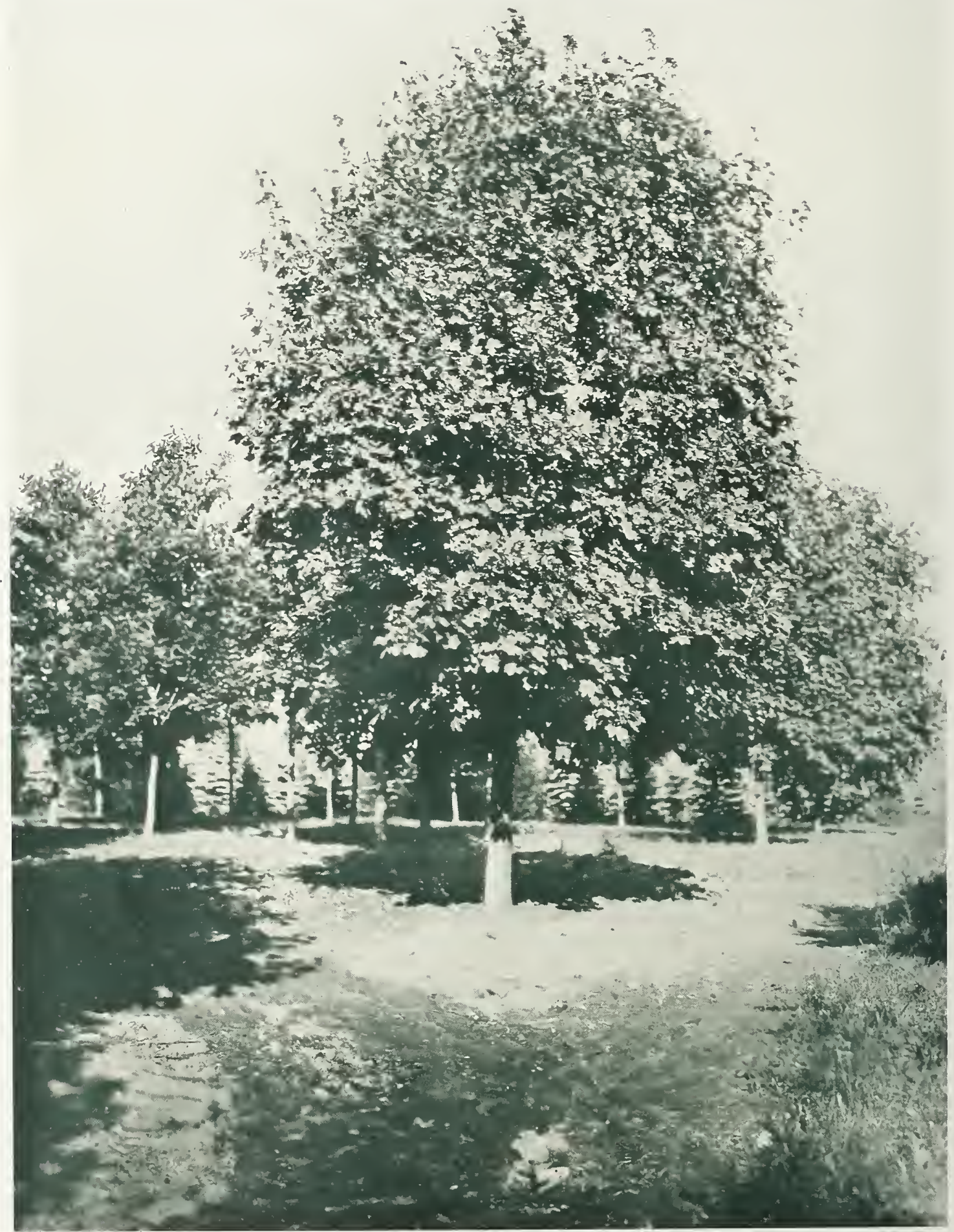

Norway Maple, nine inch caliper, thirty-three feet high. 


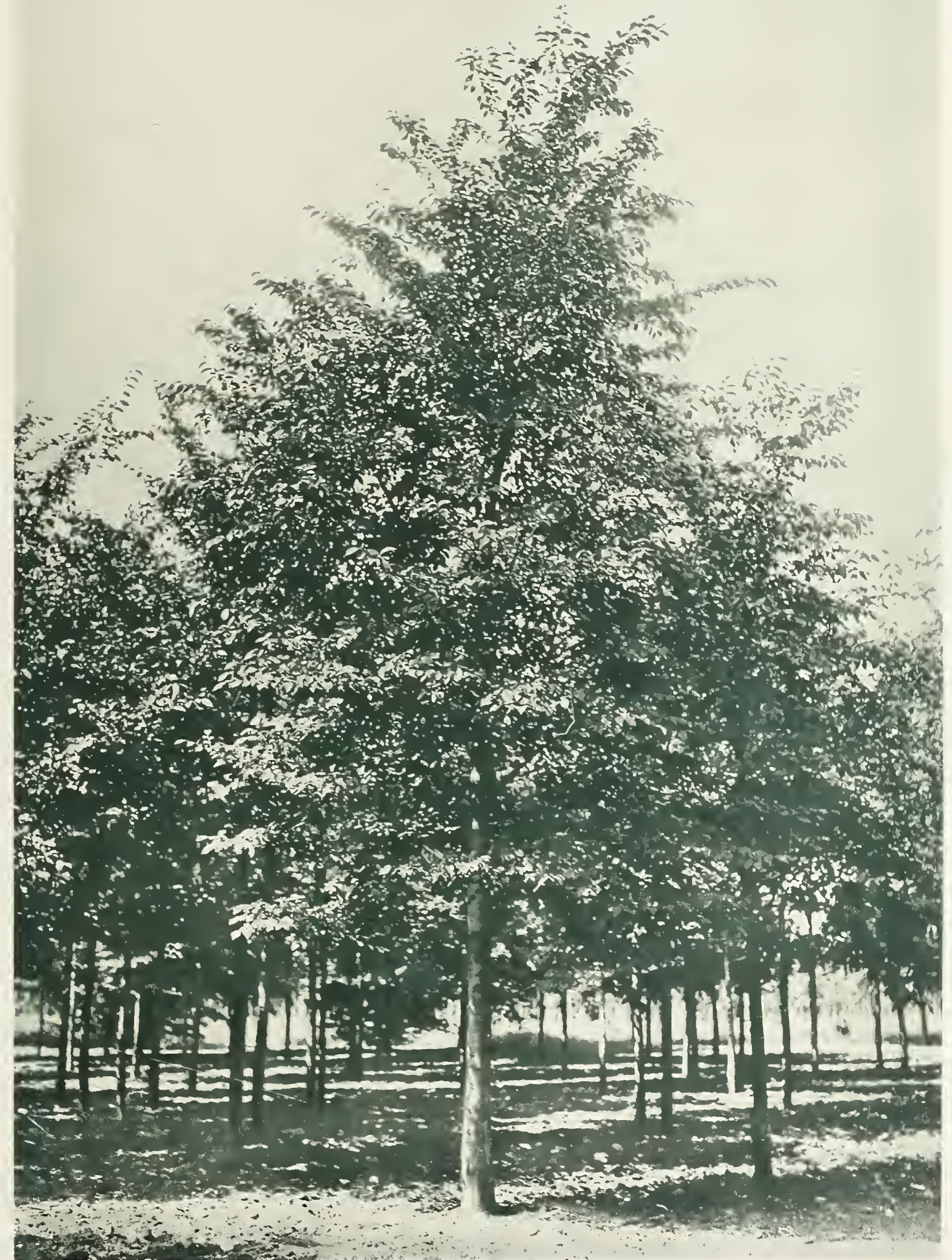

European Elm, nine inch caliper, thirty-five feet high. 


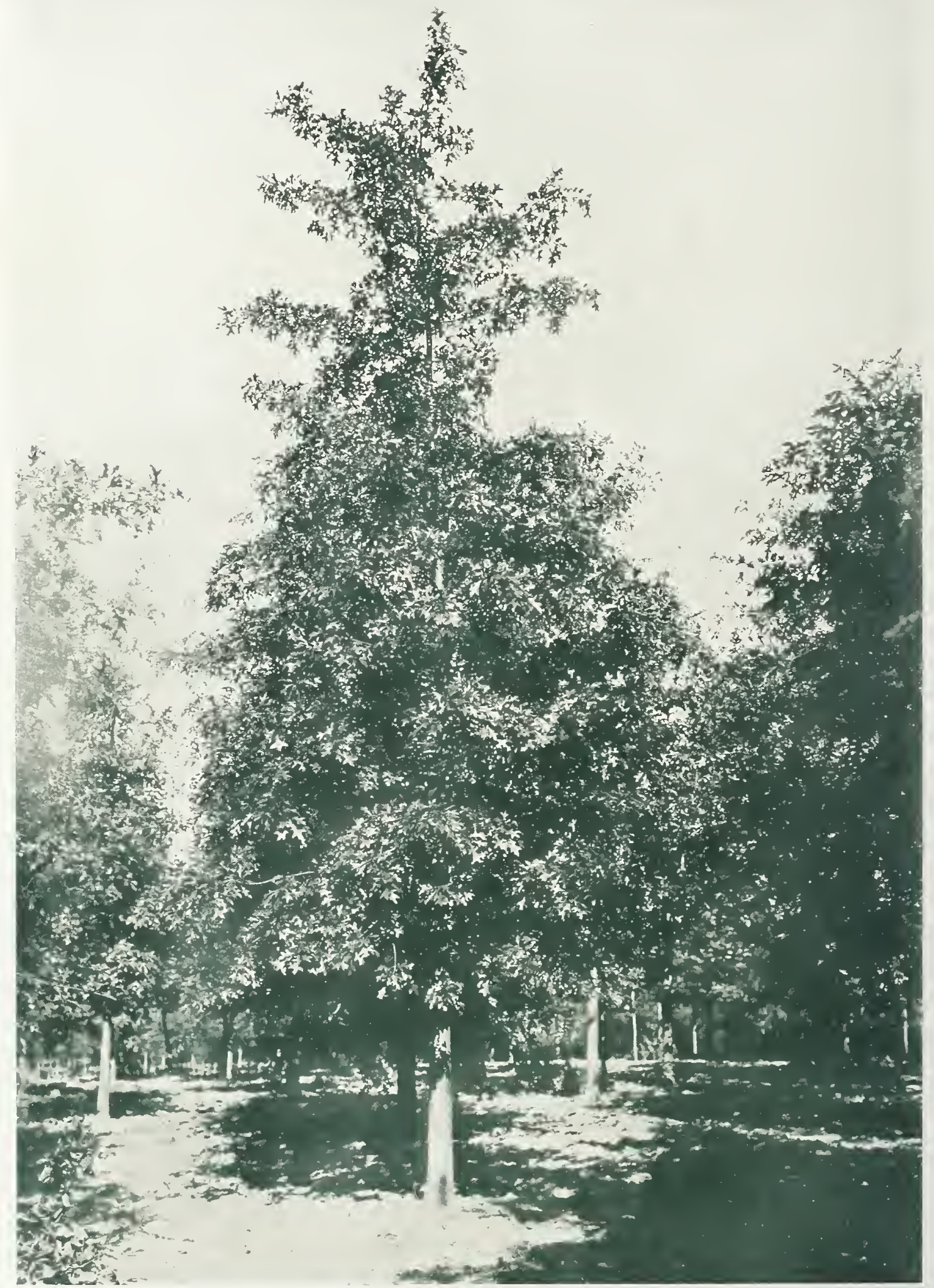

American Pin Oak, eight inch caliper, thirty feet high. 

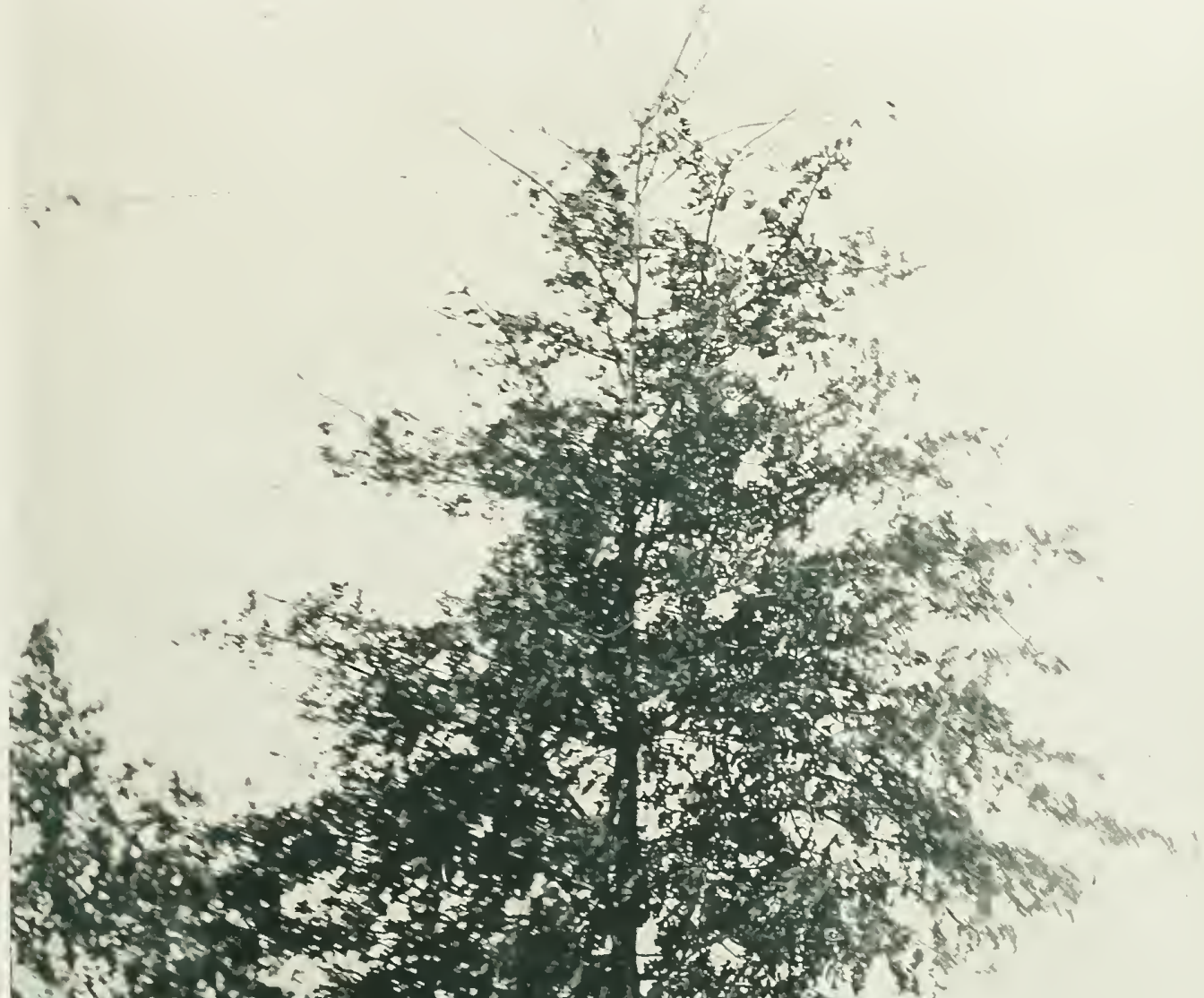

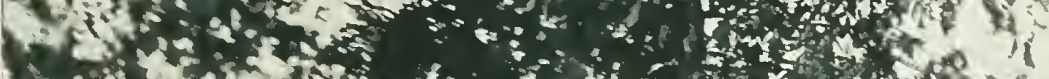

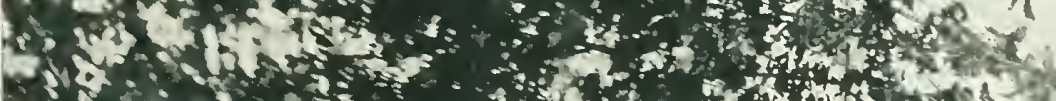

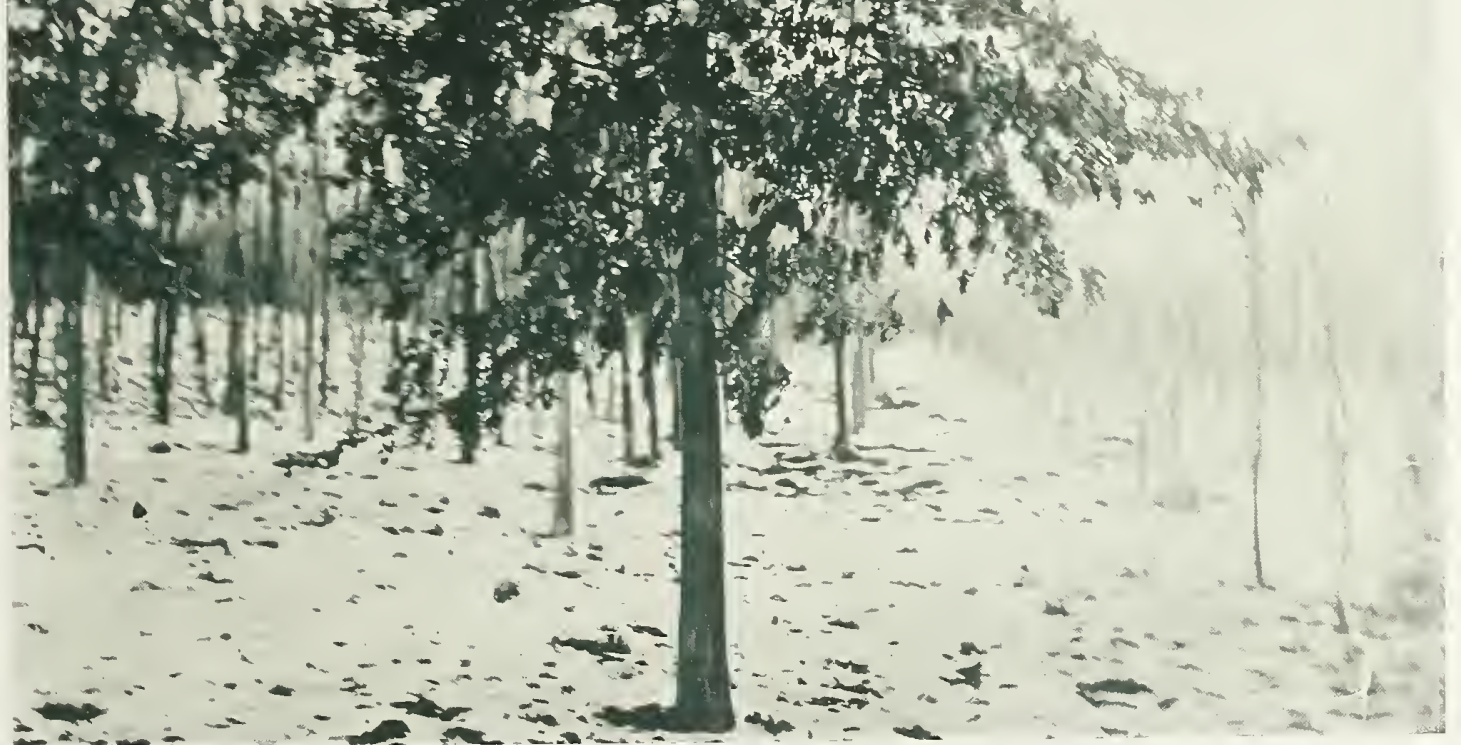

Like the Beech, the Oaks hold most of their leaves during the winter. 


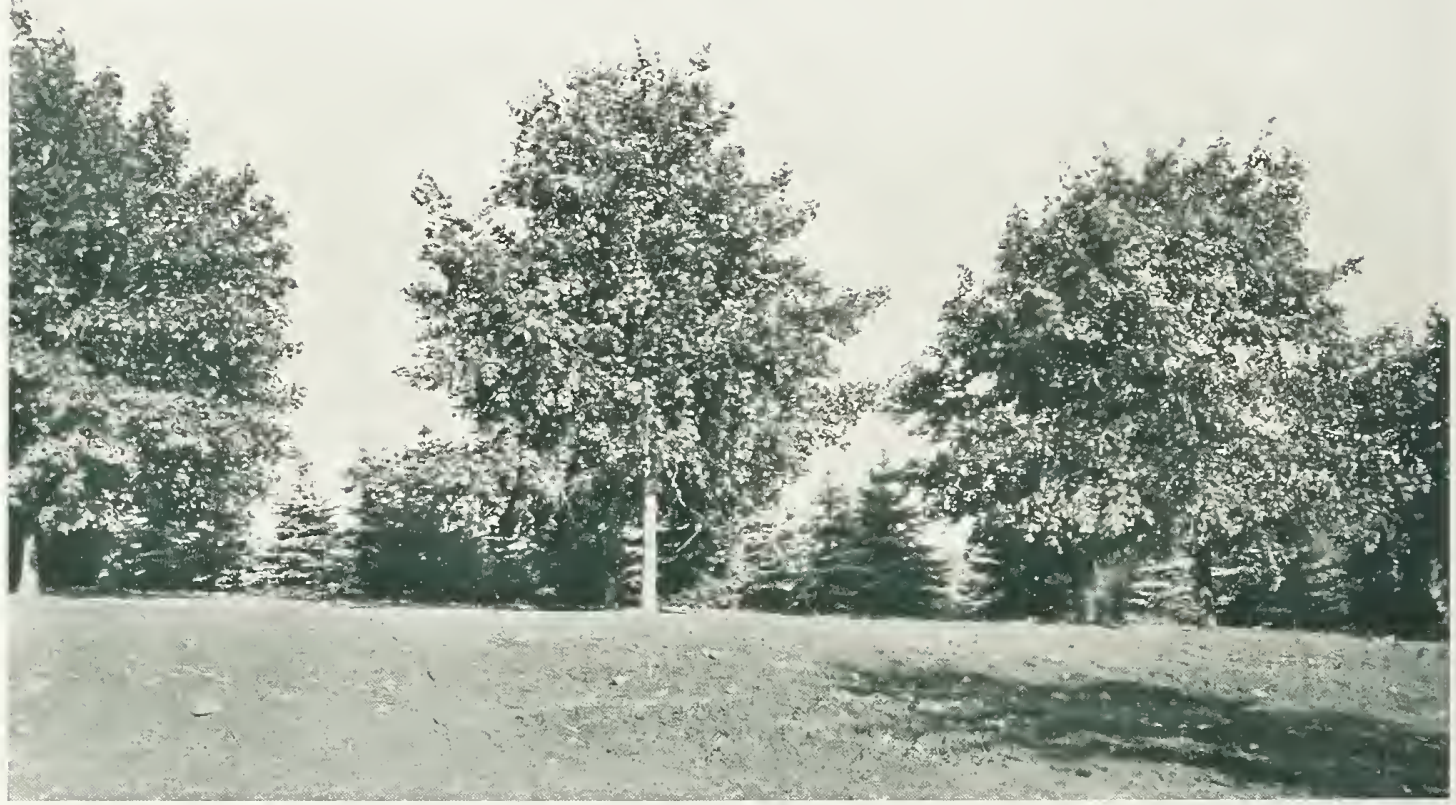

Typical Amawalk Norway Maples, eight inch caliper, thirty feet high.

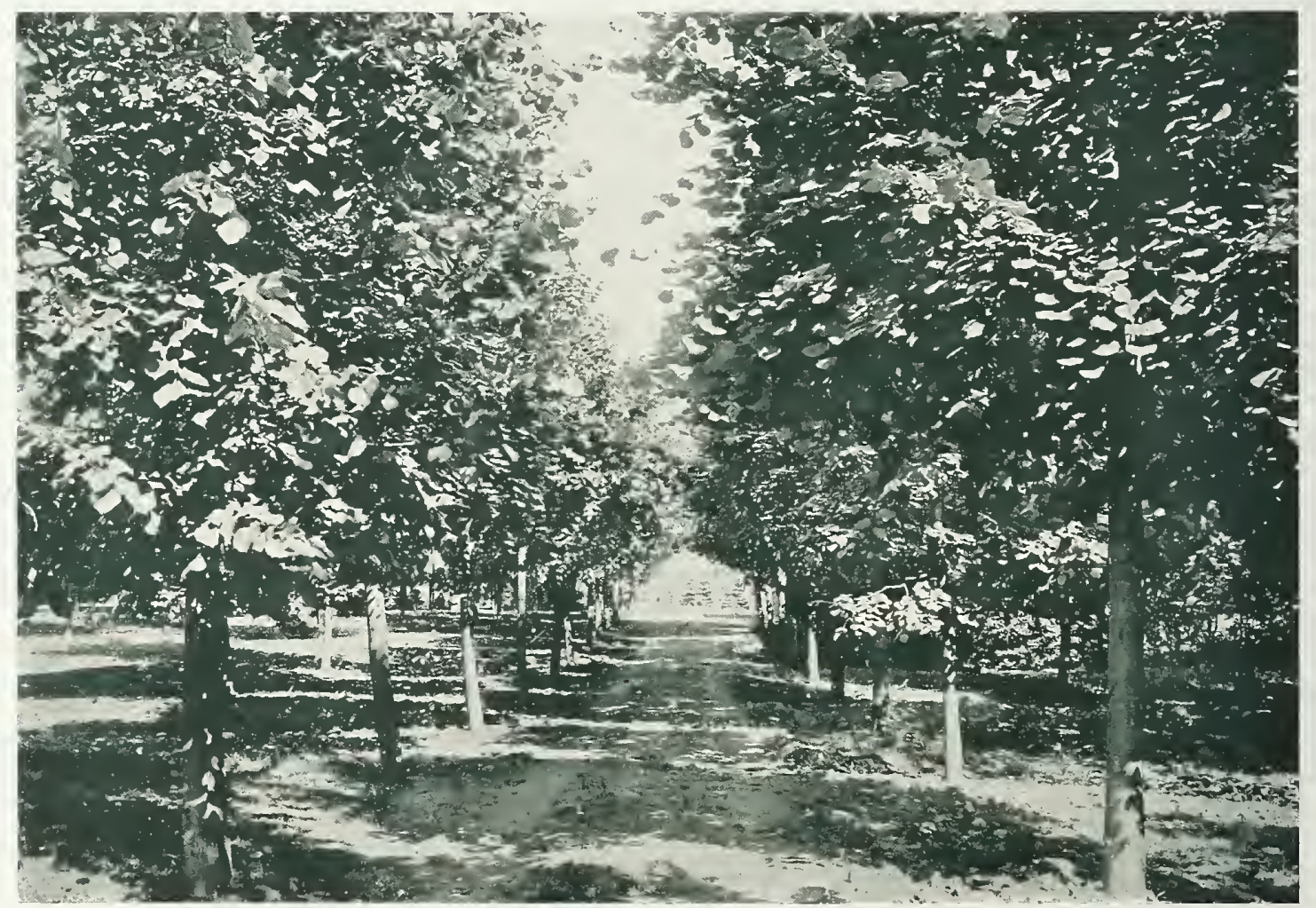

The European Silver Linden makes an effective avenue tree 


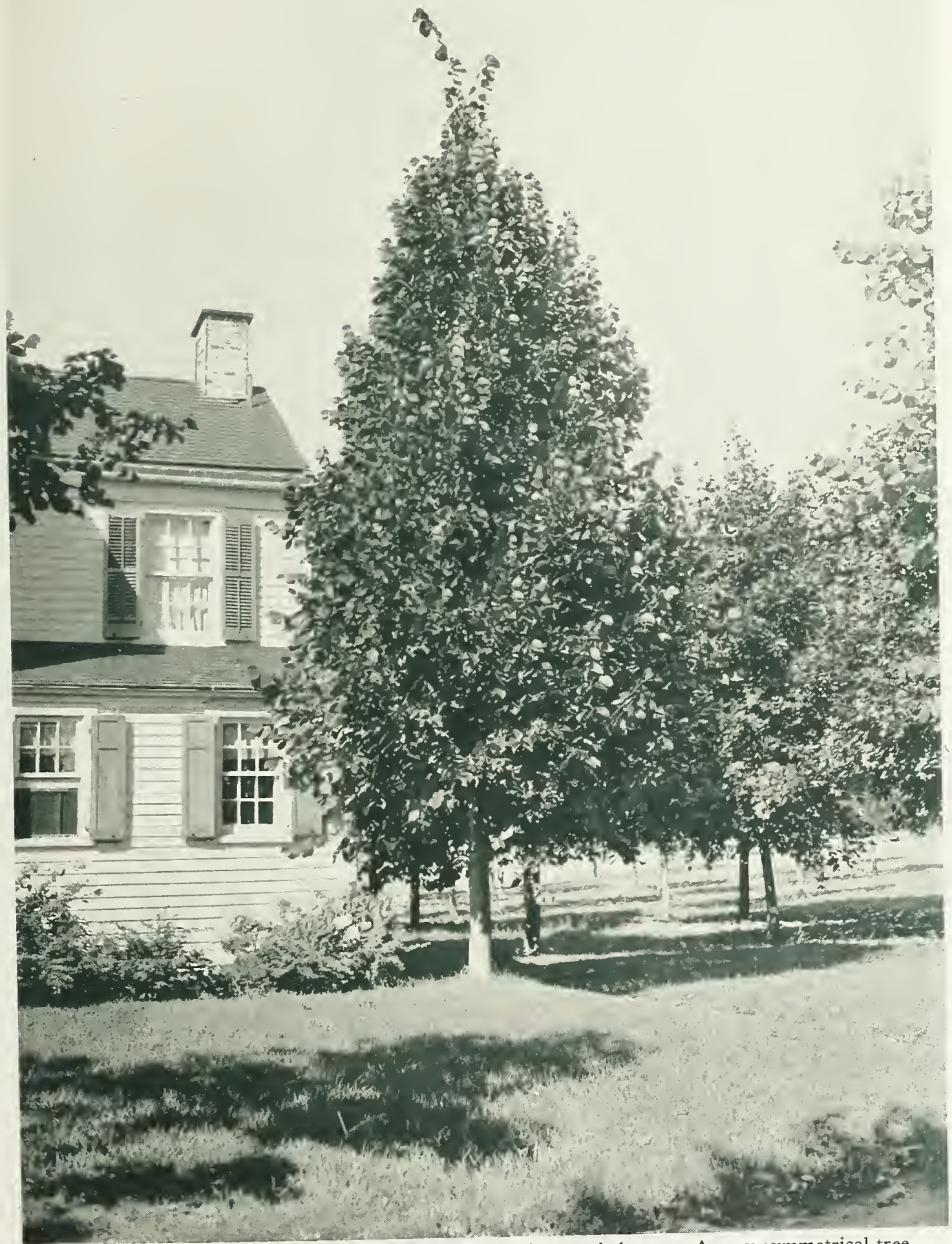

A corner of a block of American Lindens beside a foreman's house. A very symmetrical tree. 


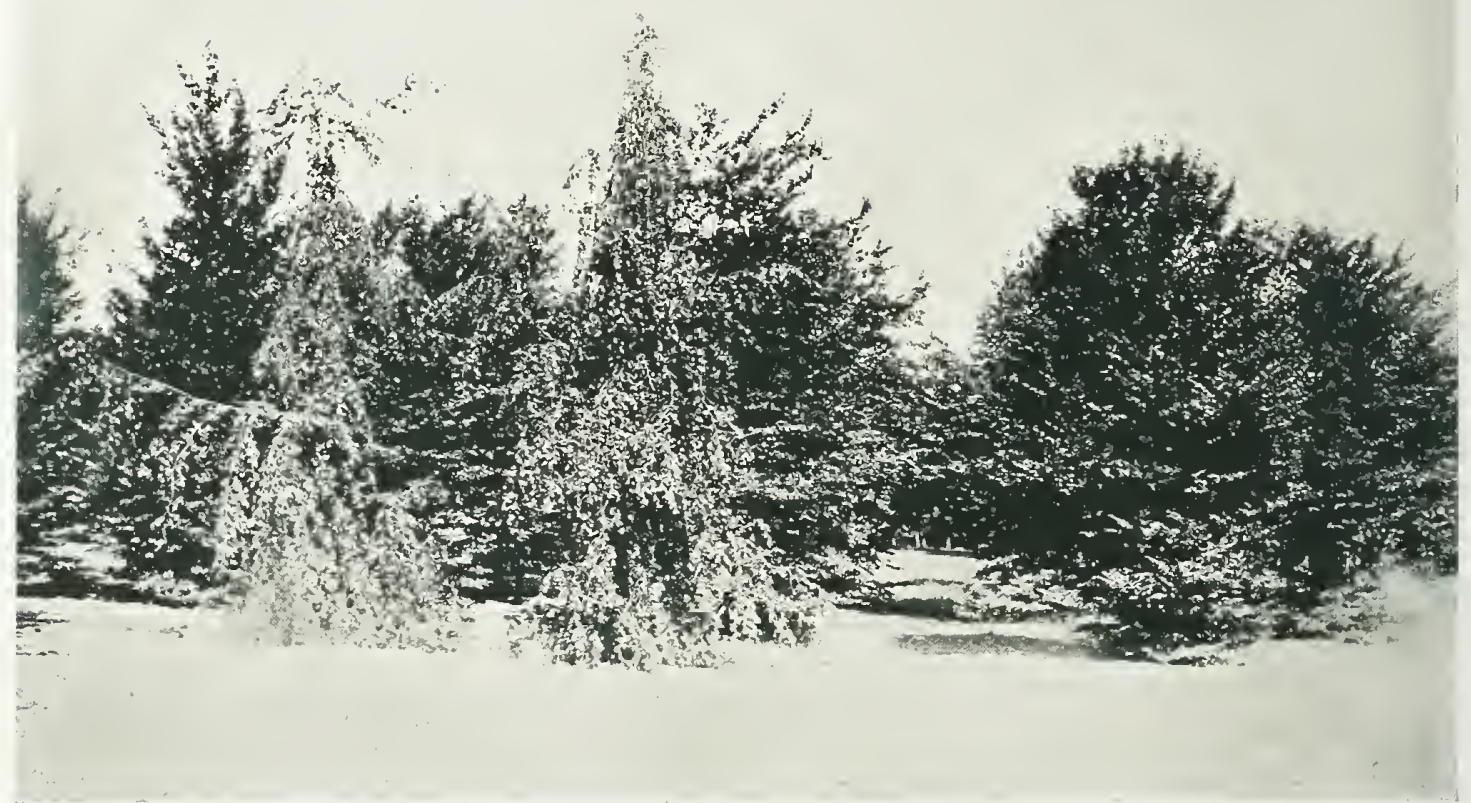

Weeping Beech and European Beech, showing the two varieties. These Beech are twenty feet high.

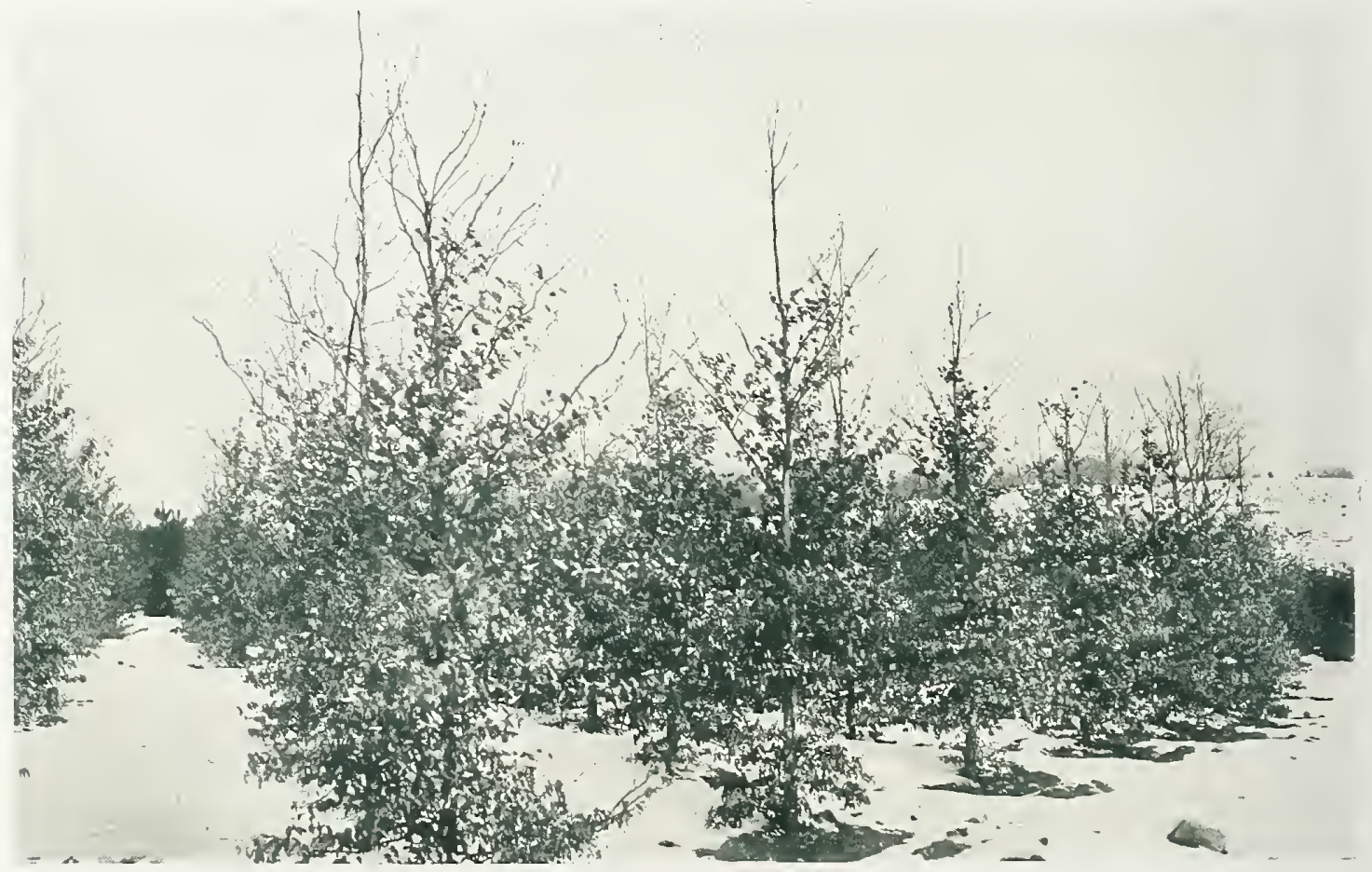

Portion of a block of European Beech that we sell for hedge planting, as on the opposite page. 


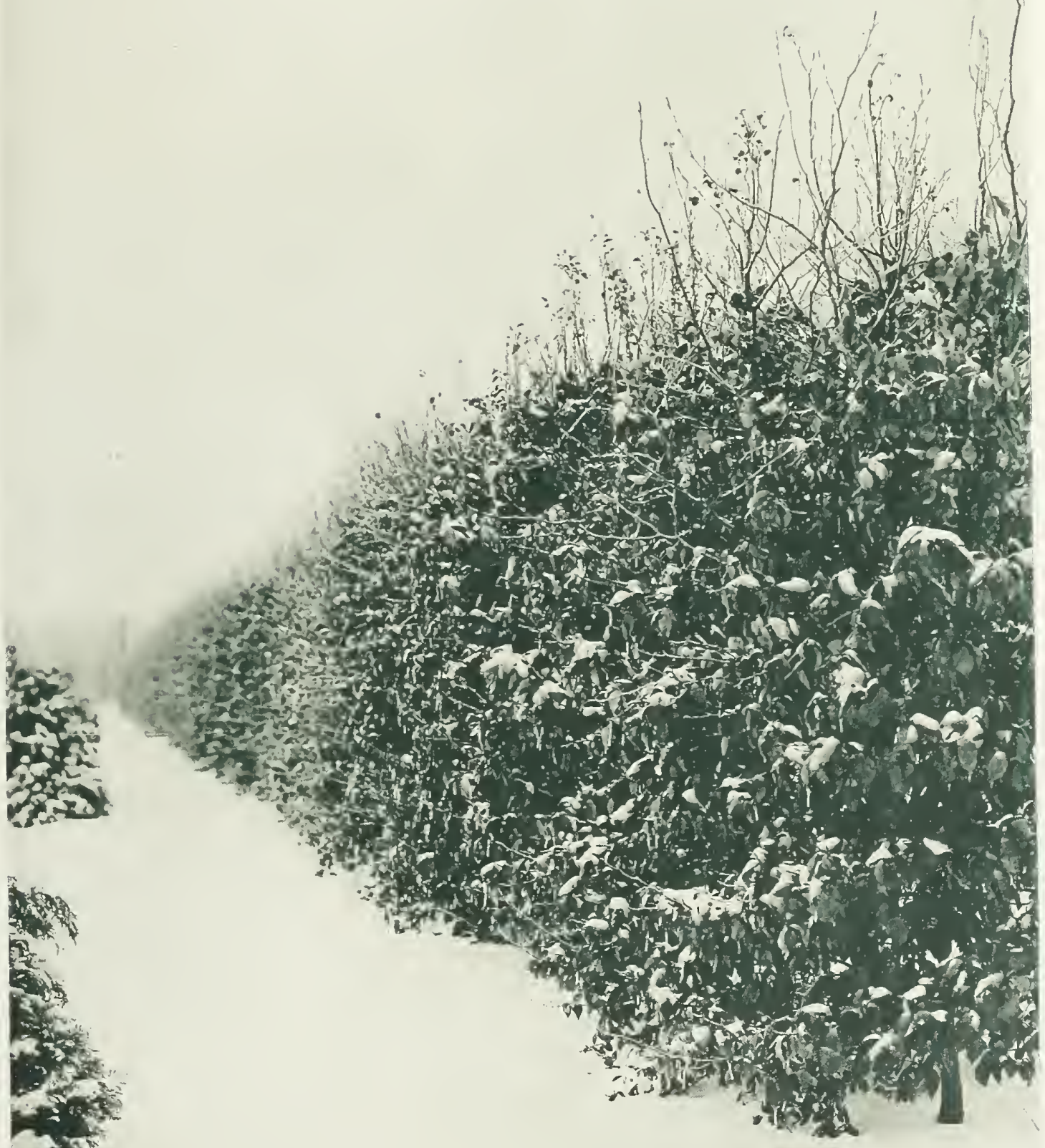

A hedge of European Beech in winter. 


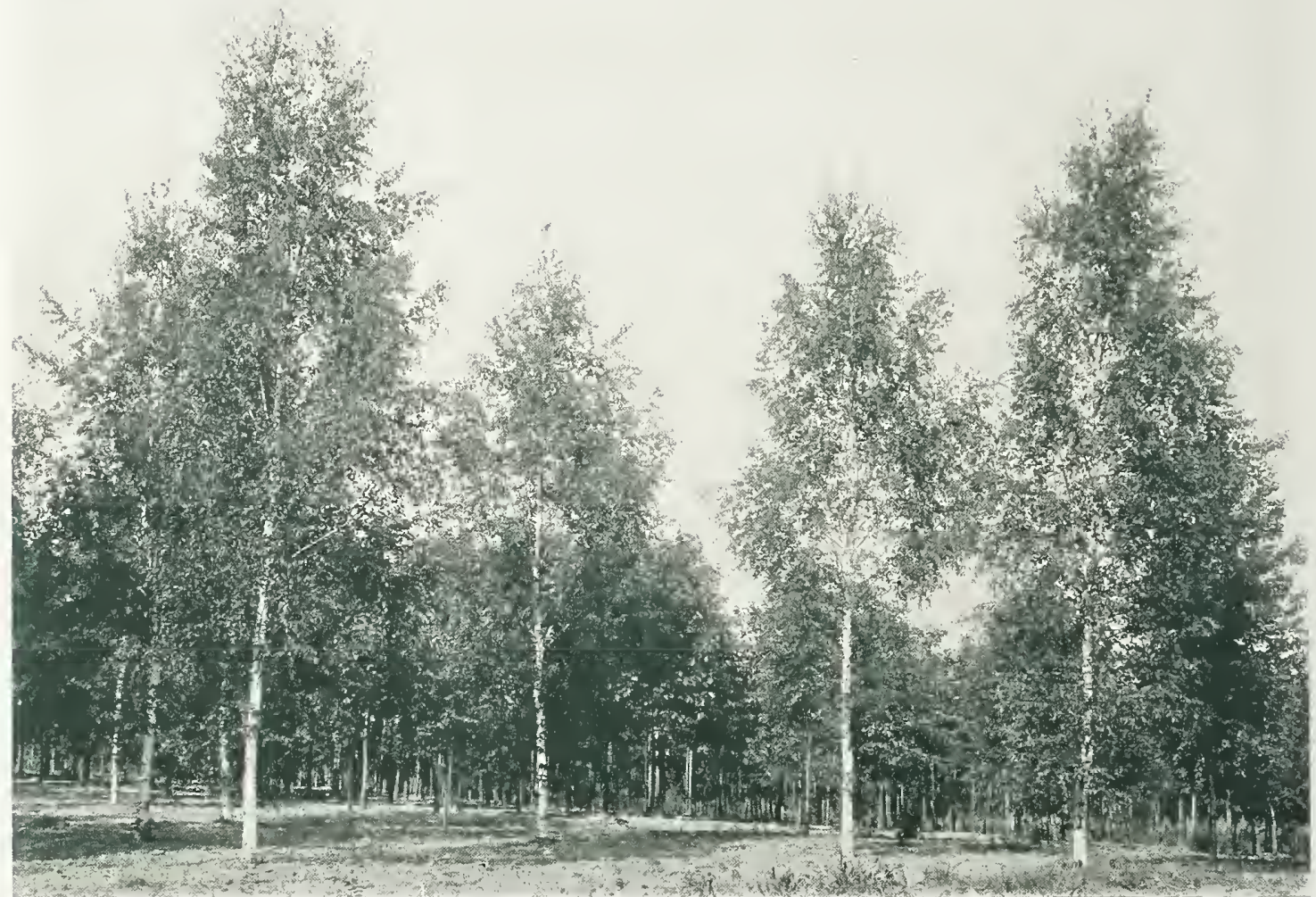

A group of Cut-leaved Weeping White Birch.

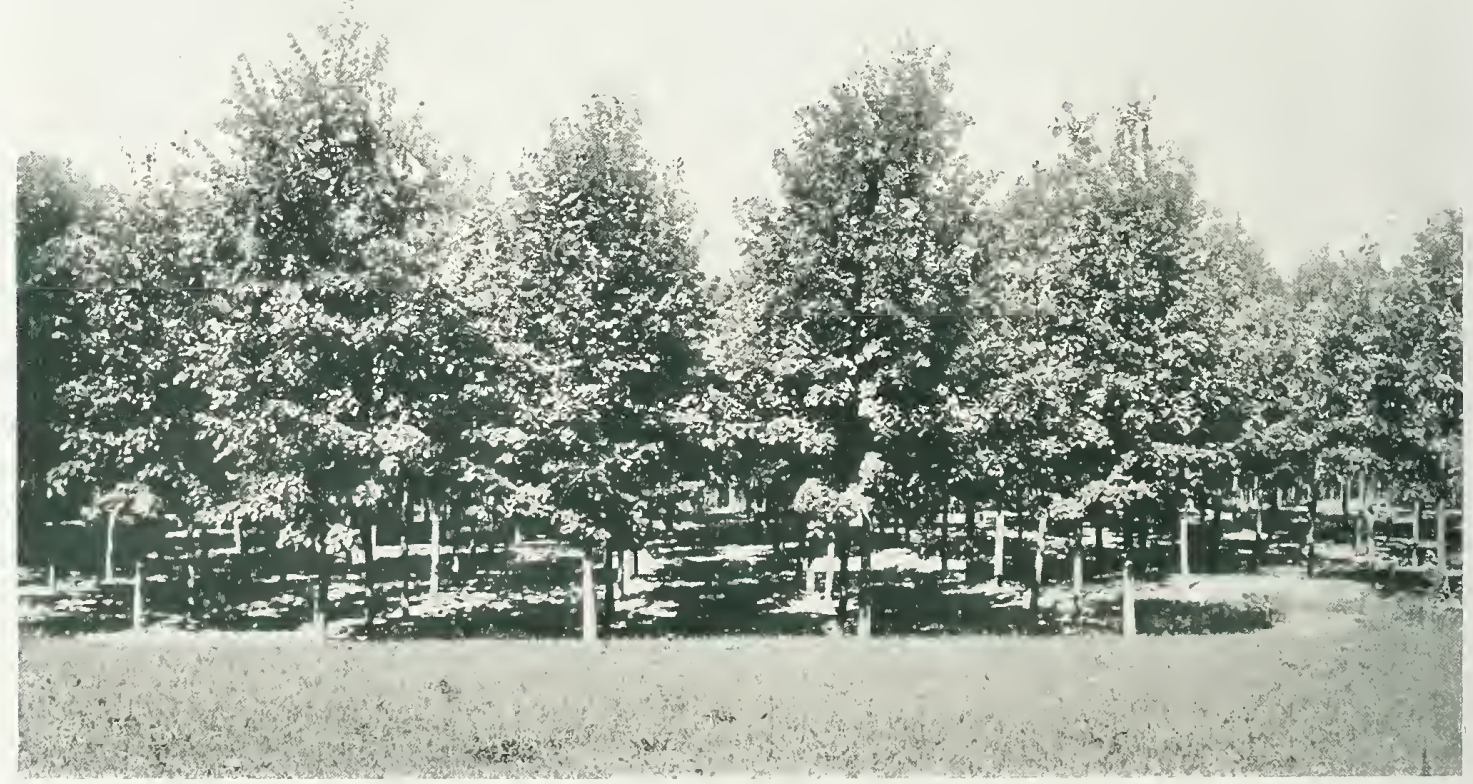

A block of Maples five to six inch caliper, twenty-five to thirty feet high.

Every tree is given ample room in which to develop in the nursery rows. 


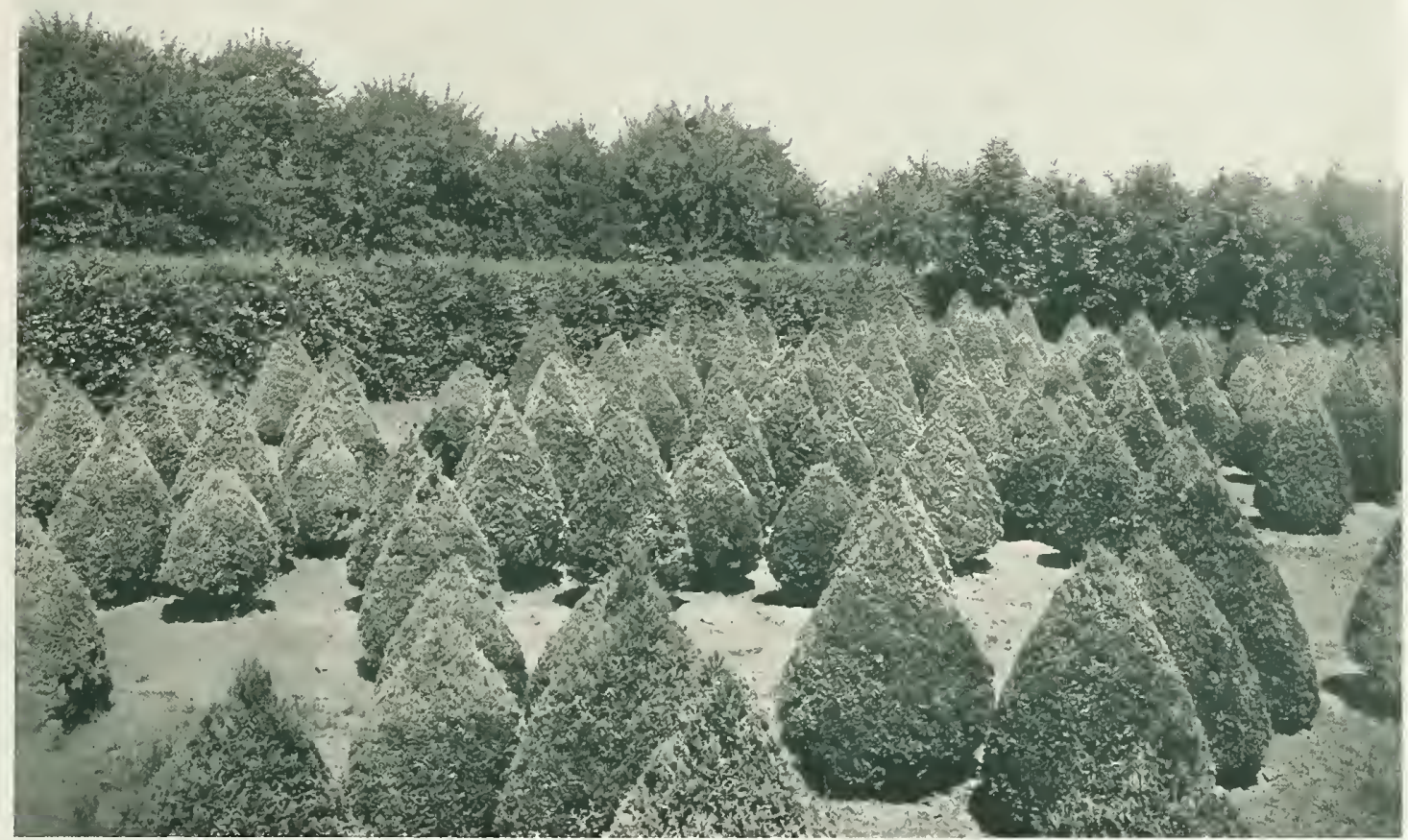

A block of Retinospora Plumosa Aurea seven to nine feet high, closely sheared for formal planting. European Beech hedge in background.
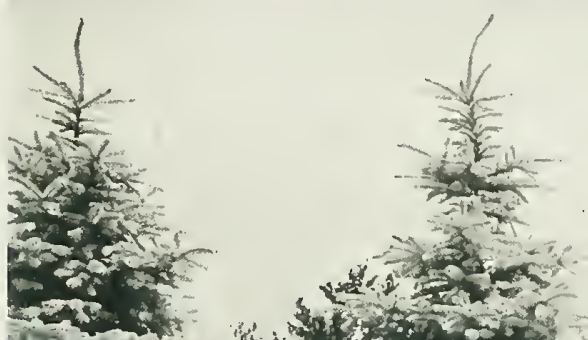

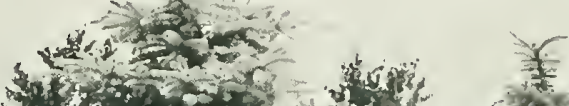

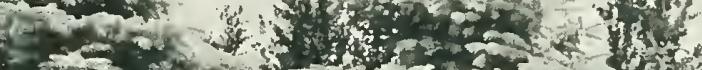

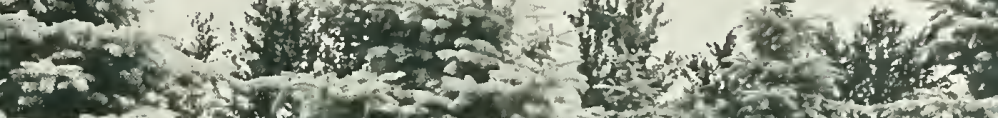
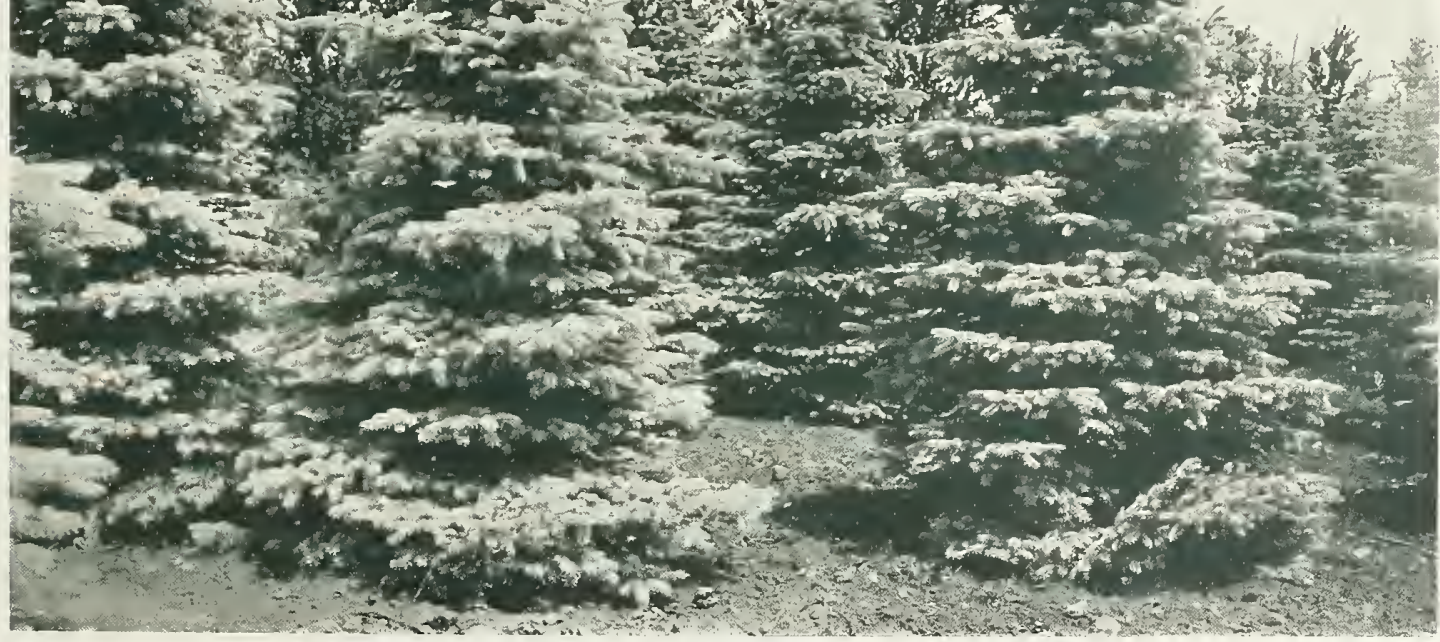

In a block of Koster Blue Spruce twelve to fourteen feet high. 


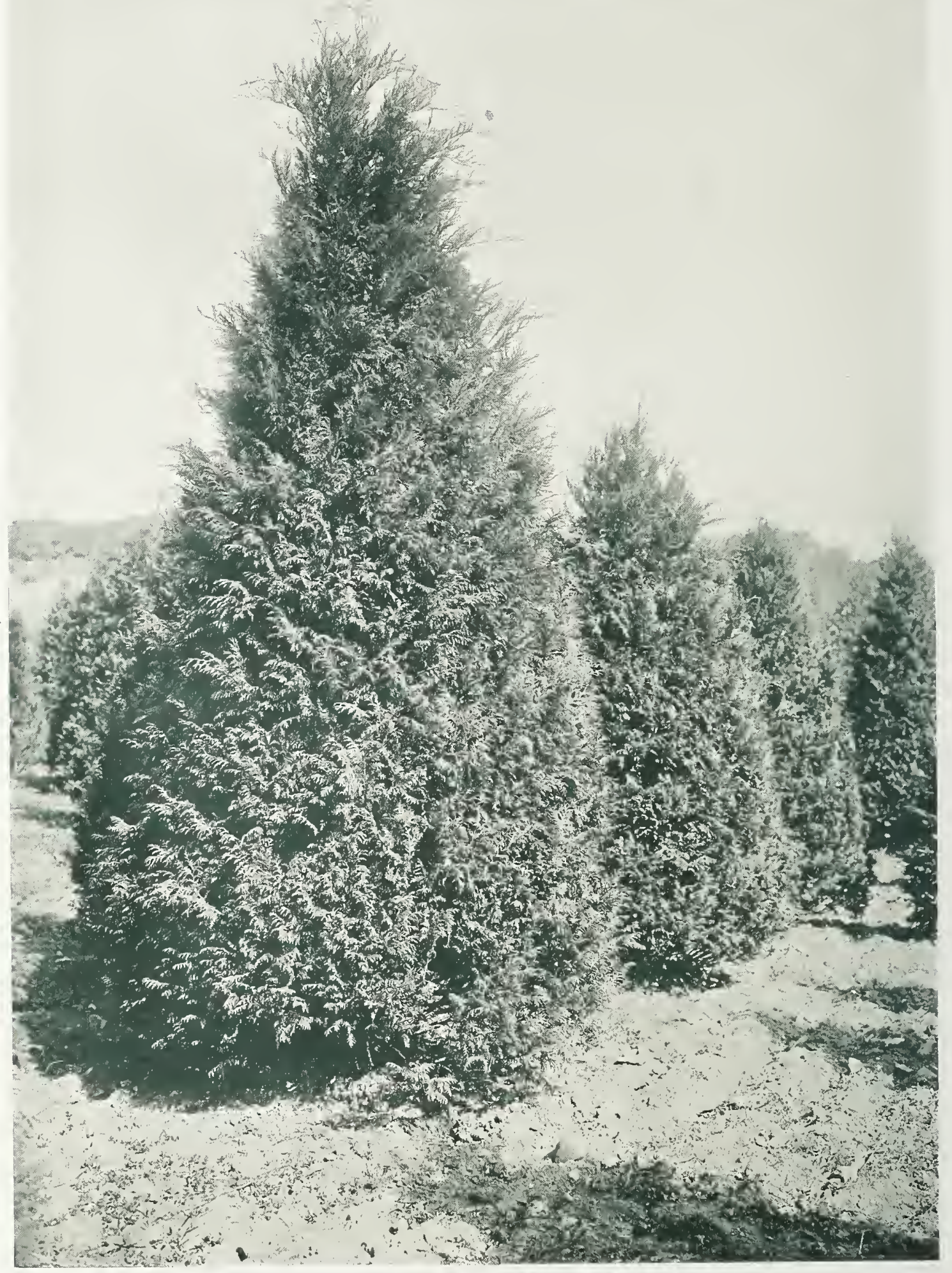

Sheared Retinospora Pisifera Aurea, twelve feet high. 


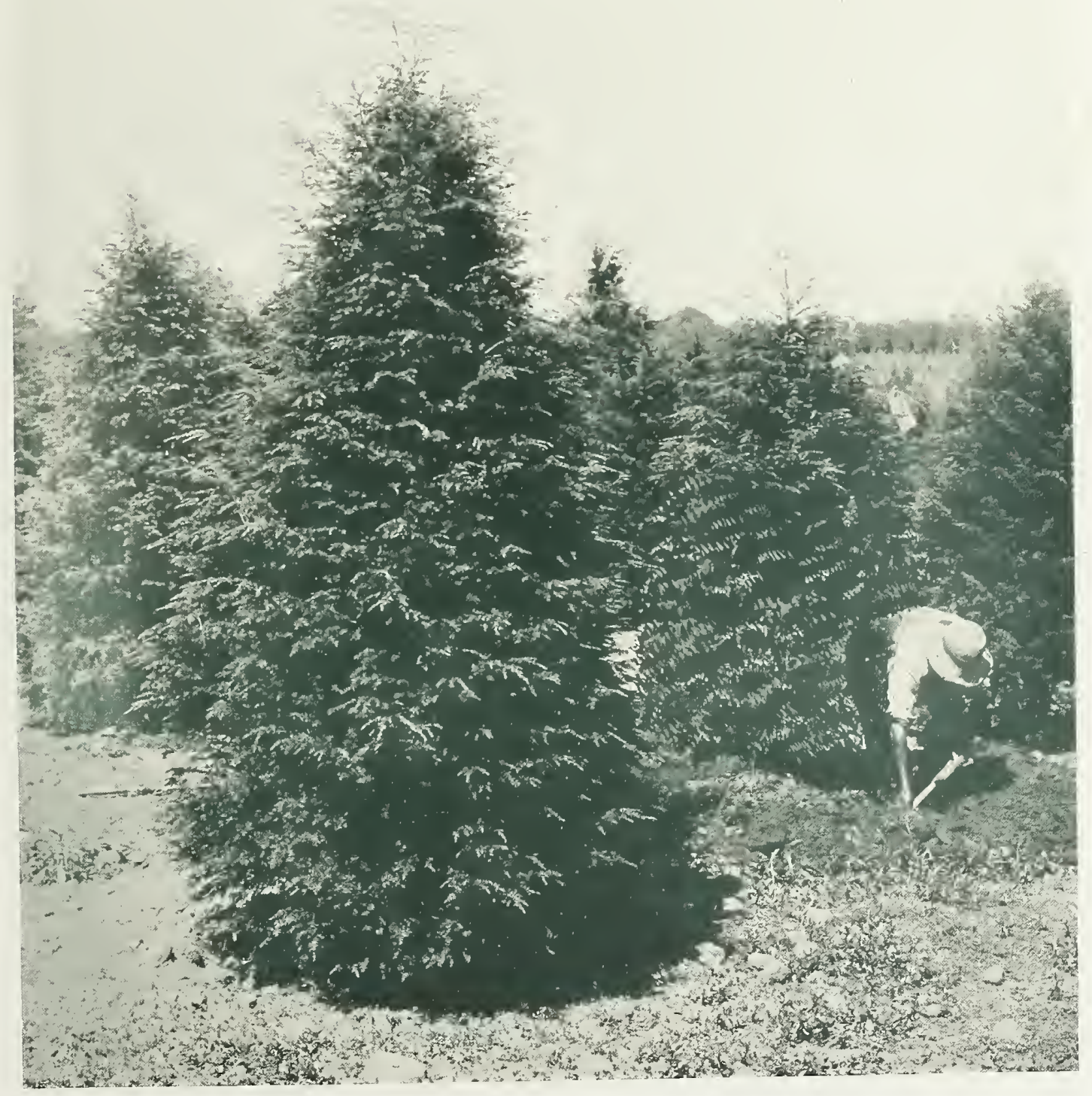

A block of Hemlocks ten to twelve feet high.

All our Hemlocks have been repeatedly sheared to make them full and bushy. 


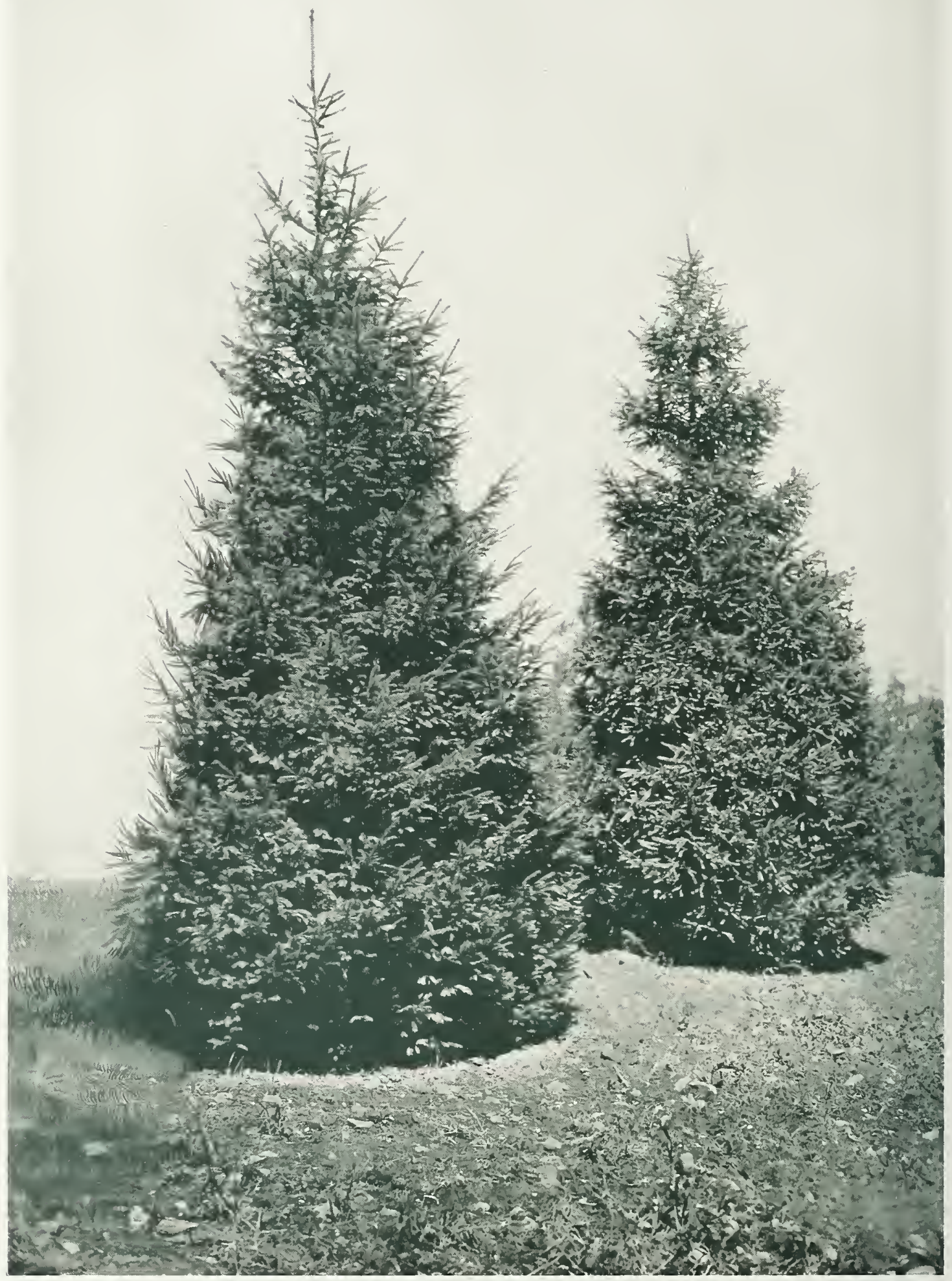

Norway Spruce eighteen feet high. Immediate effects can be obtained by planting these trees. 


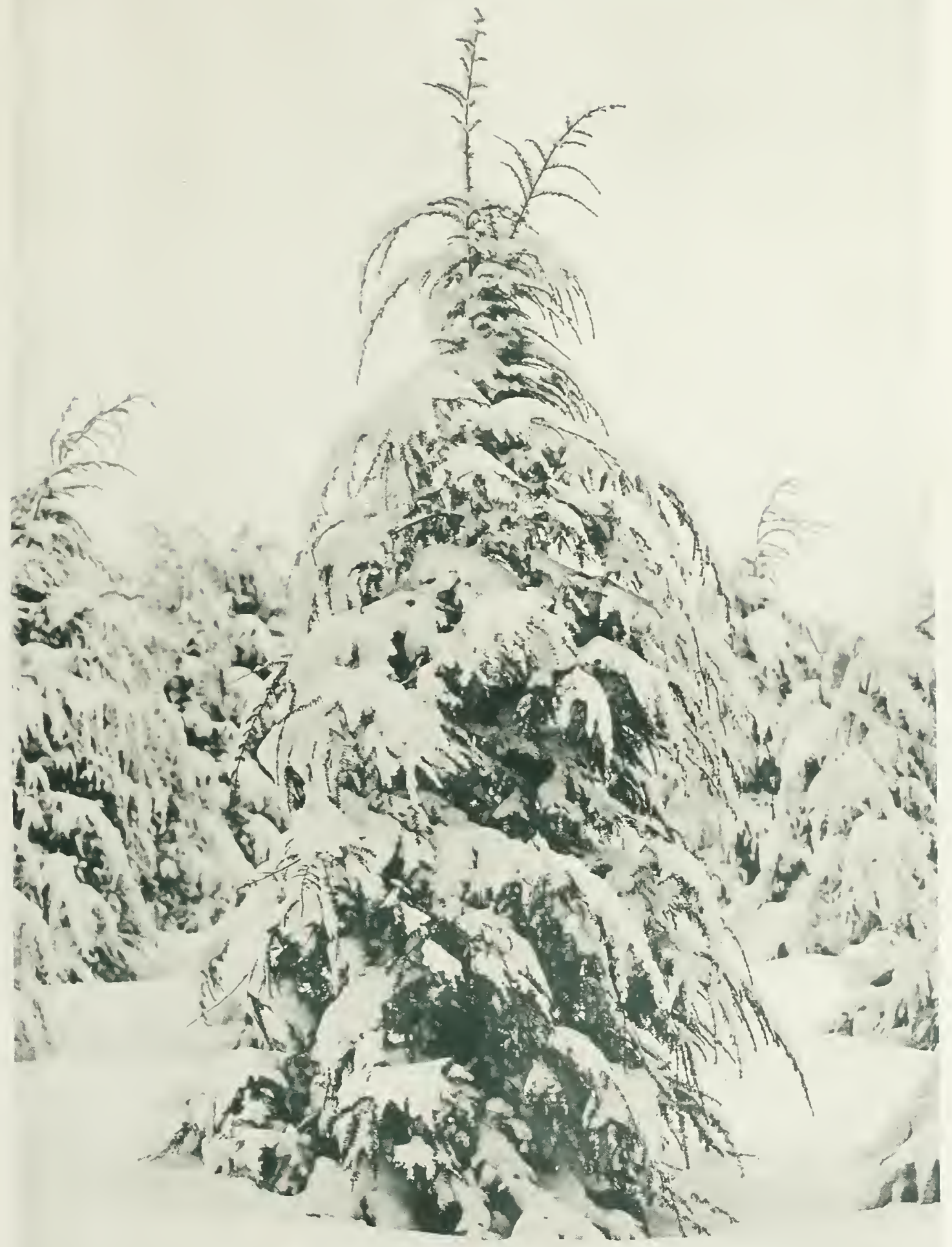

Evergreens make a beautiful effect in a winter landscape. 


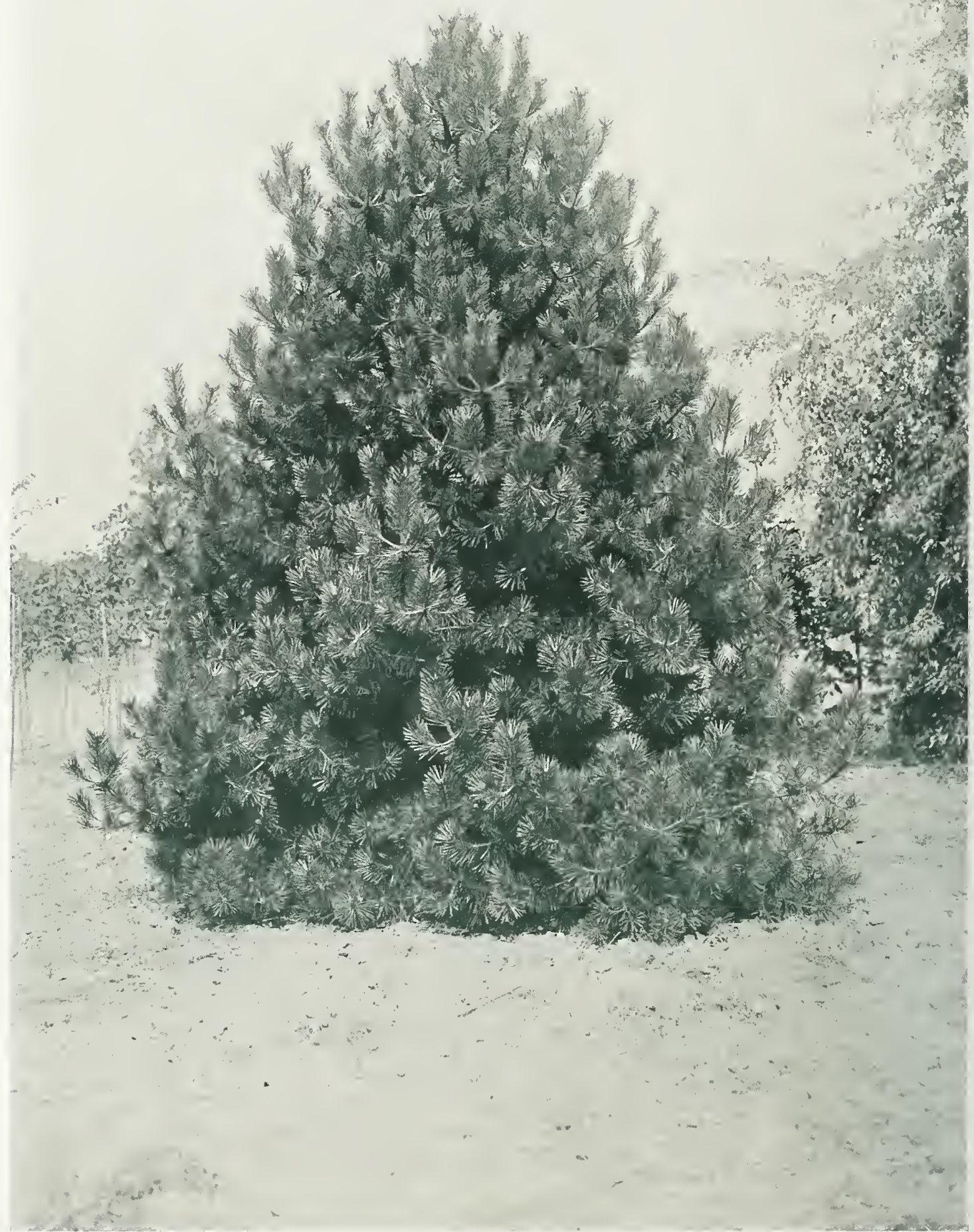

An Amawalk Austrian Pine eighteen feet high, showing the full, dense growth of all our Pines. 


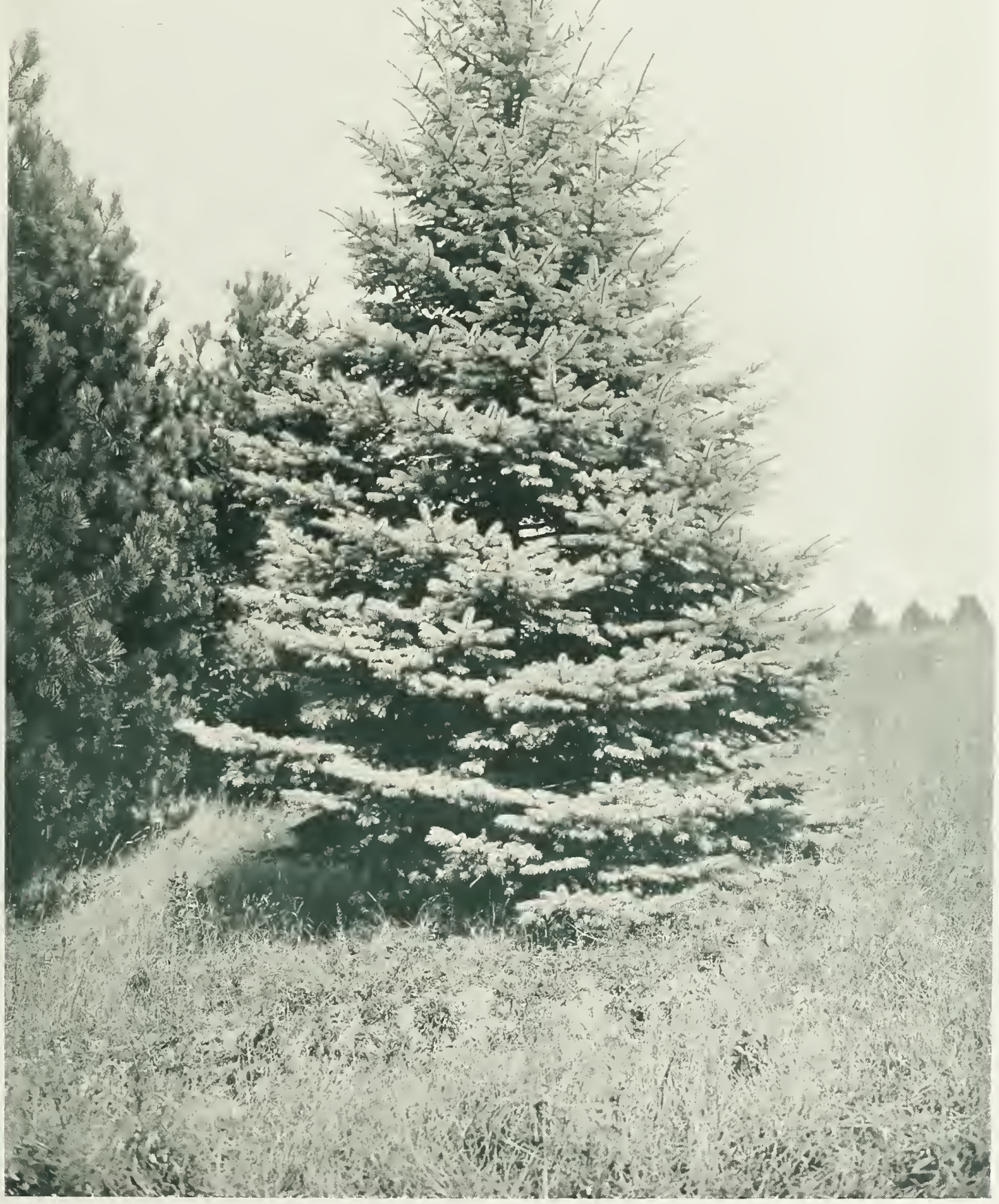

The Colorado Blue Spruce is an evergreen of great beauty and dignity. 


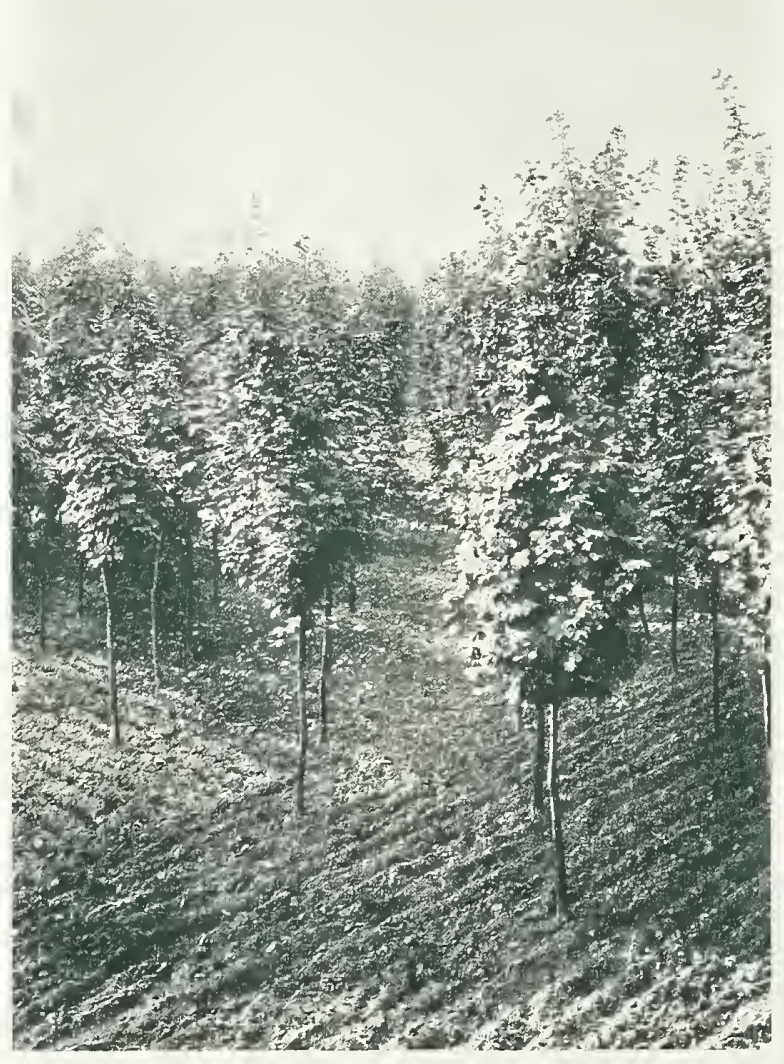

Showing how

we cultivate

our trees

both ways in

the nursery

rows to

obtain symmetrical

root development.

We dig our evergreens and certain deciduous trees (such as the Beech, Dogwoods and Hawthorns) with a ball of earth. The balls of the large trees are secured with a canvas bag and a wooden platform.

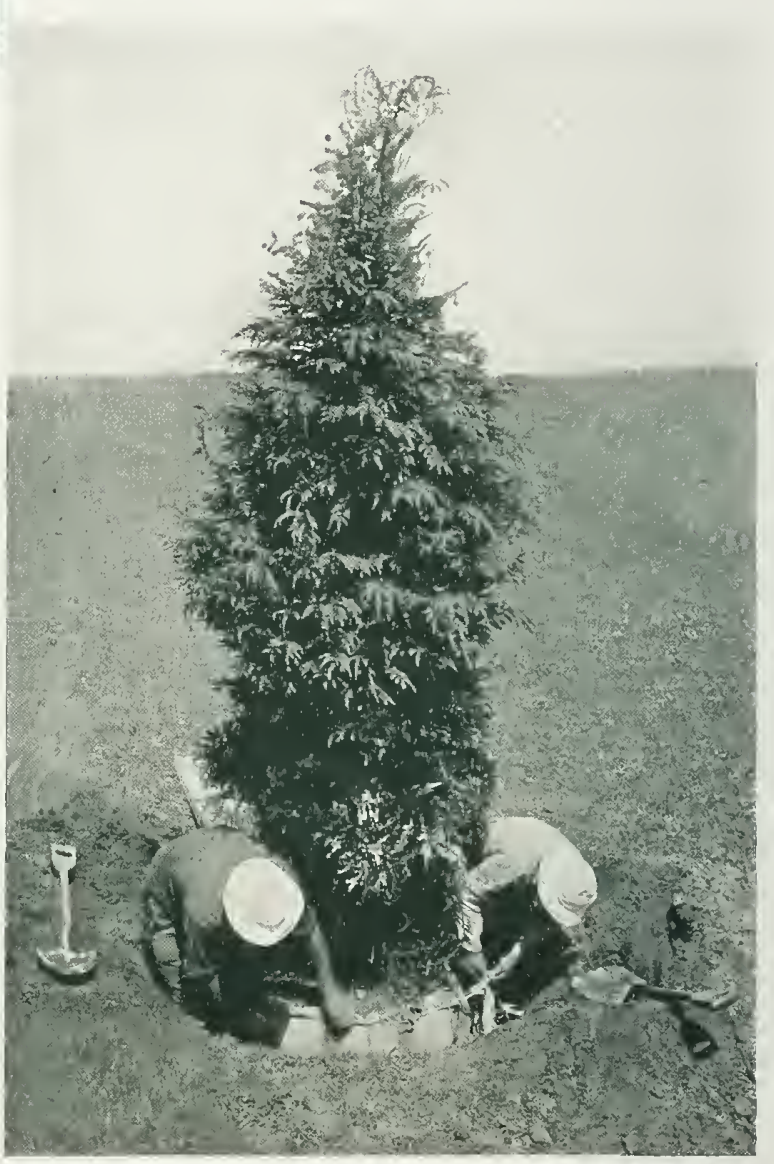




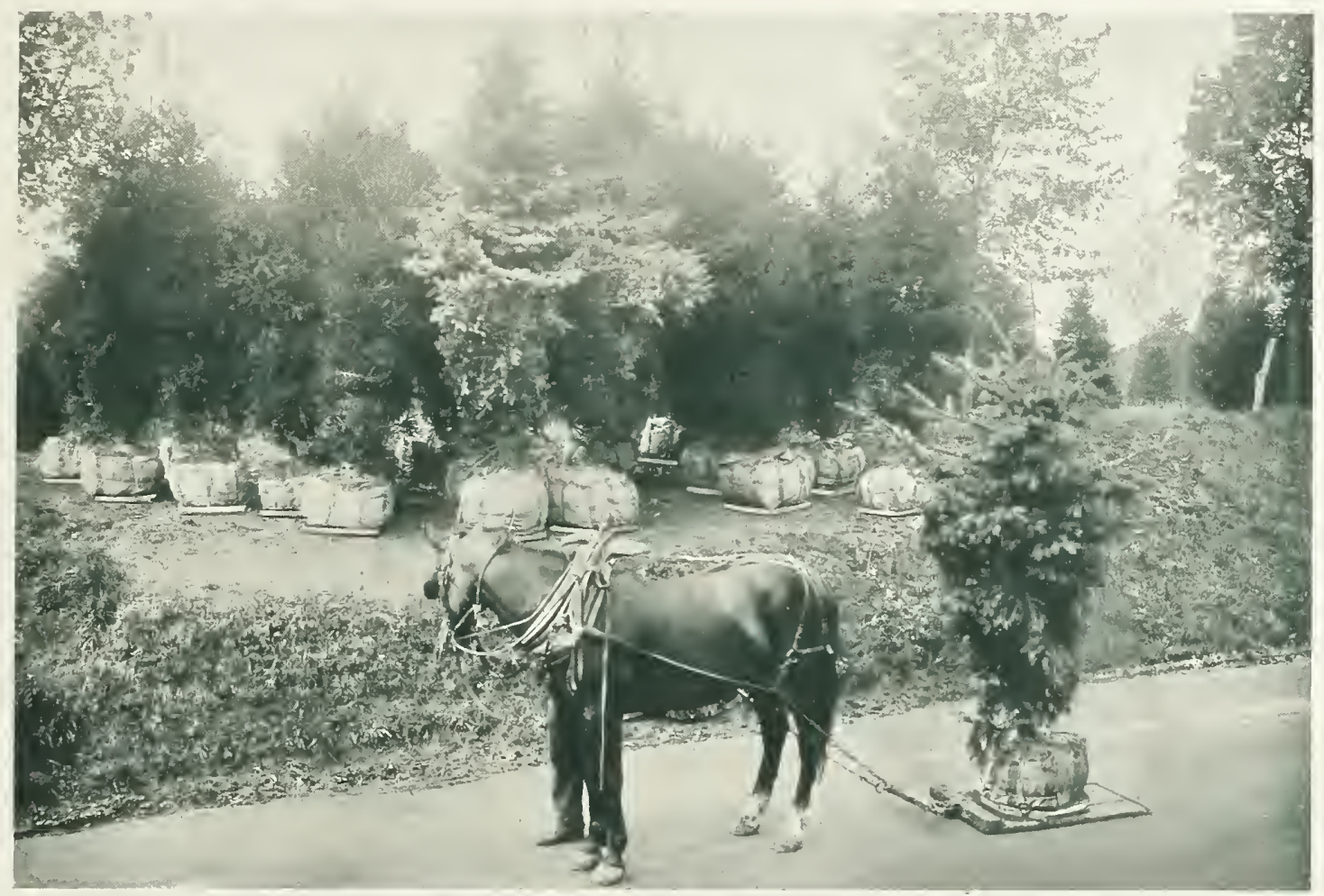

All our trees are stone-boated from their holes to the loading mounds.

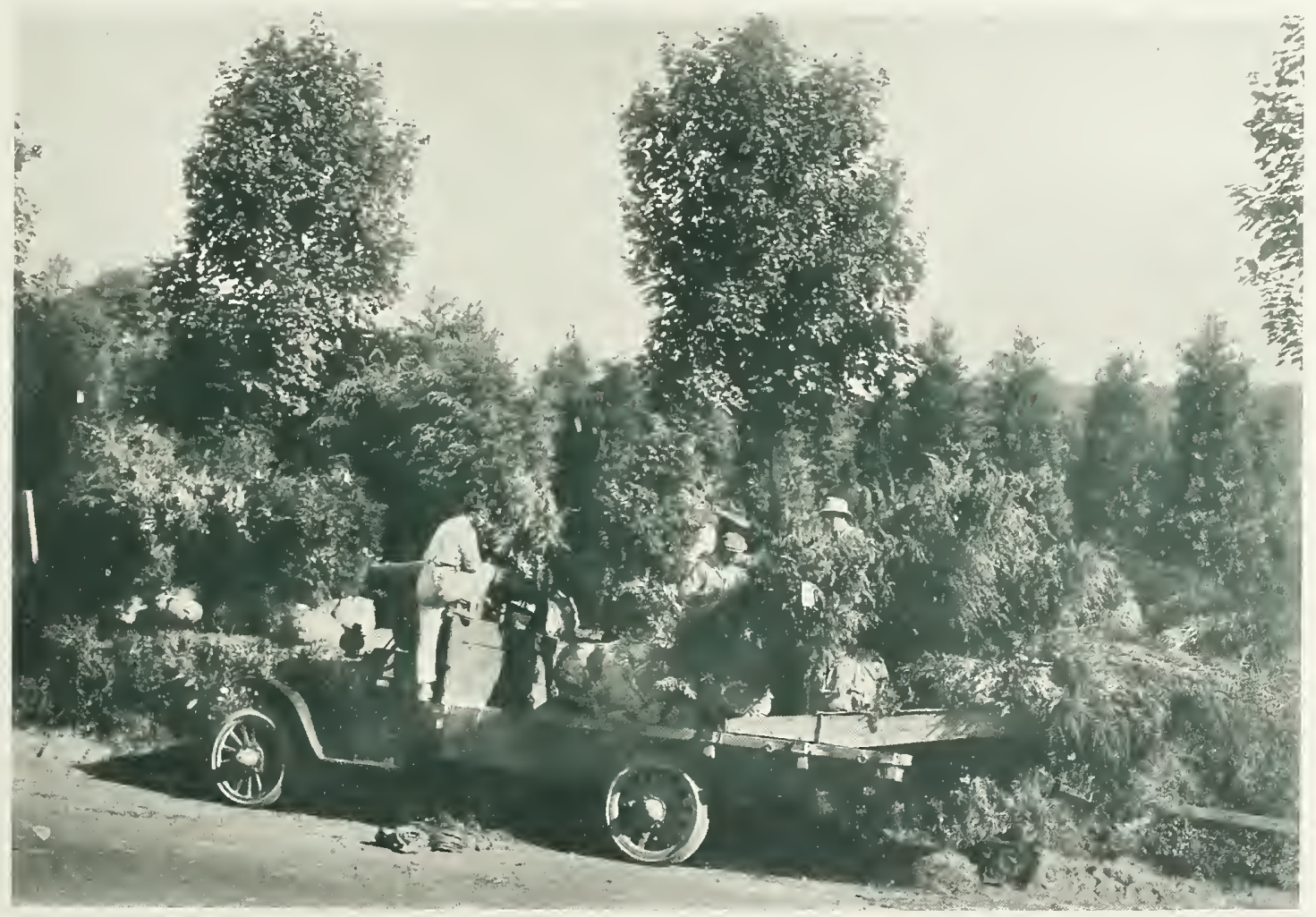

Loading a truck with an order of mixed evergreens. 

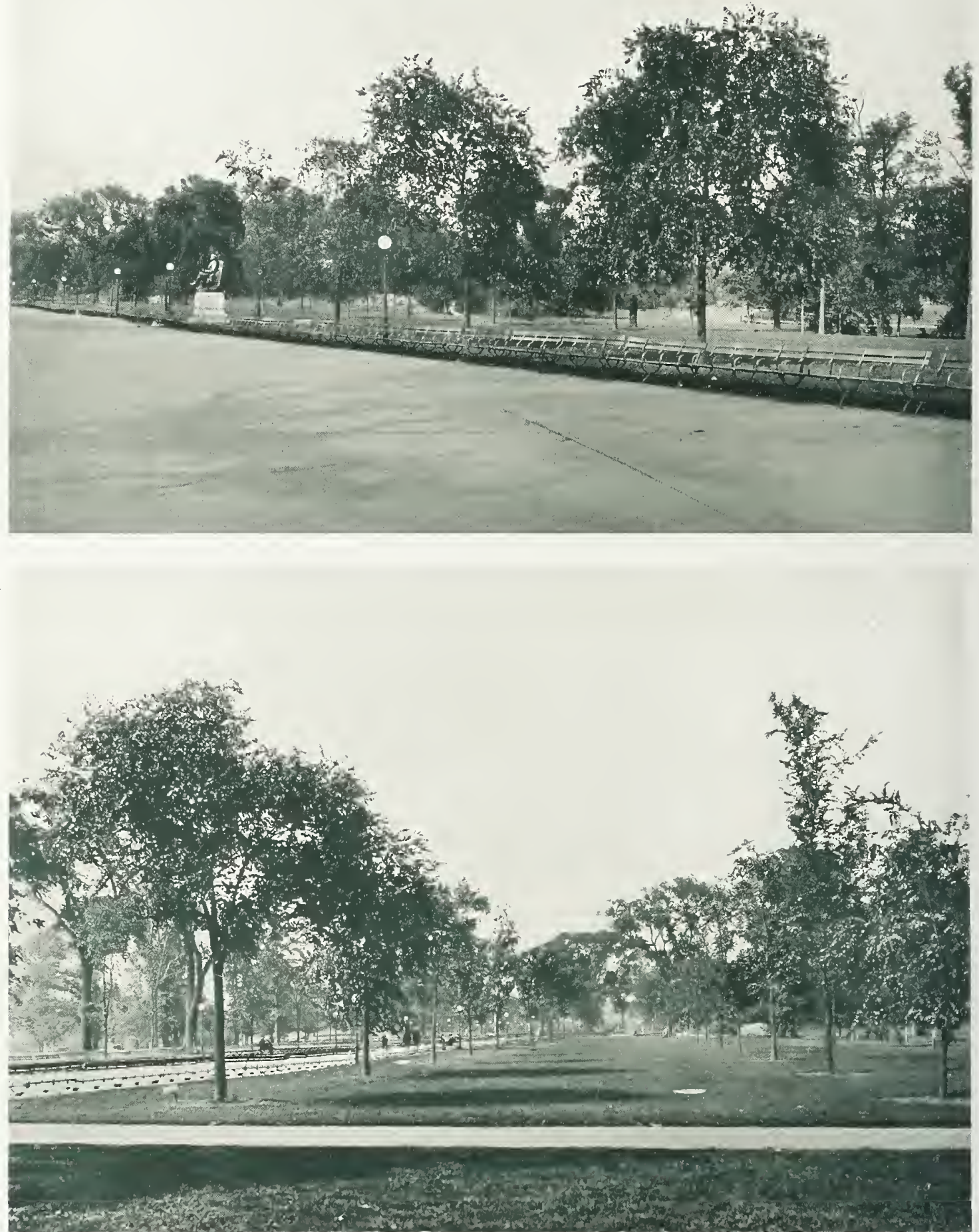

Many of the American Elms on the Mall in Central Park, New York, were replaced during 1918-1919 with Amawalk American Elms.

Sixty-eight trees were planted, all of which have done well. 


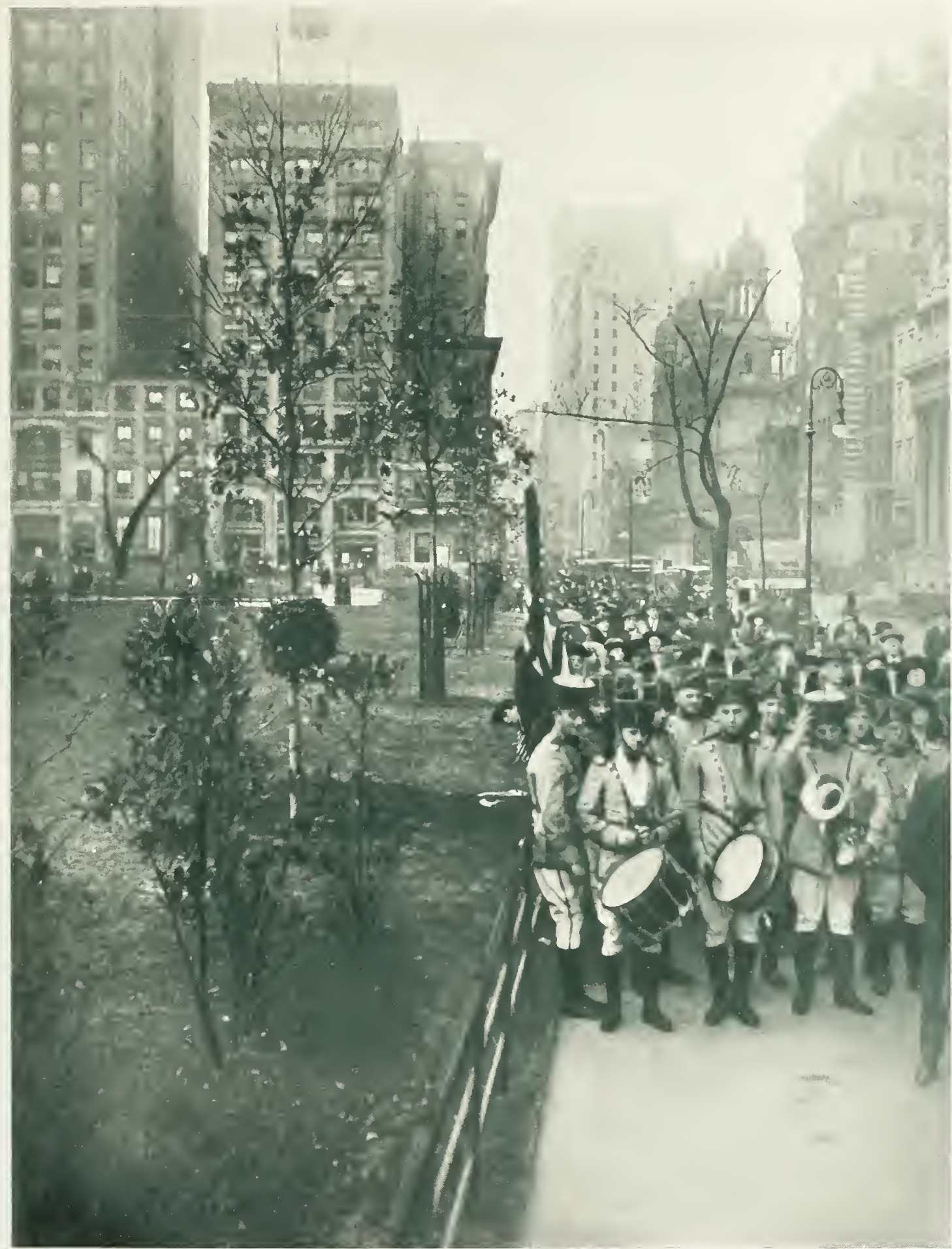

A memorial planting of Amawalk Red Oaks in New York City in 1920. 


\section{Prices, Delivery and Guarantee}

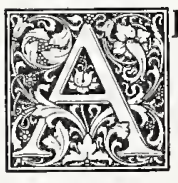

LL the trees listed in this catalogue measure up to the highest requirements of specimen trees. No inferior trees are offered for sale. The yearly output of the Amawalk Nursery is about 10,000 Specimen Deciduous and Evergreen Trees. To produce that number, we have growing about 250,000 trees of all sizes.

As none but specimens are sold, customers are allowed to select by tagging any tree growing in our Nursery at the catalogue price for its variety and size. The price per tree is the same regardless of the quantity ordered.

The catalogue price of our trees includes their proper digging, balling where necessary, and loading on trucks or in freight cars. All evergreens and certain deciduous trees (such as Beech, Dogwoods, and Hawthorns) are dug with a ball of earth. The balls of smaller sizes are secured with burlap, and the larger sizes with a canvas bag and wooden platform. This insures the least possible disturbance of the roots.

The prices in this catalogue are f. o. b. Amawalk. Deliveries can be made by freight, express or motor truck. For freight shipment the cars are packed on our own siding. For less than car-load shipments, packing is charged for at cost. For delivery by motor truck, cost price only is charged, this charge being based upon the size of the load and the distance it has to go.

We guarantee that every tree leaving our Nursery is in the best condition obtainable by scientific care and handling. If correctly planted in suitable locations, and given adequate attention thereafter, they will live. As we have obviously no control over the treatment our trees receive after leaving our hands, we do not guarantee that they will live. To do so would mean increased prices and would place an unnecessary burden on those customers whose trees are properly cared for. However, to accommodate those purchasers who prefer their trees insured, we will for a pre-arranged premium agree to re-supply f. o. b. Amawalk any tree which fails to live.

We are anxious to co-operate with our customers in making their planting a permanent success and will advise them about the care of their trees, either by letter or personal call, without cost. 


\title{
Deciduous Trees
}

\author{
Namely, those that yearly drop their leaves

\section{Beech-Fagus} \\ The time is coming when the value of the

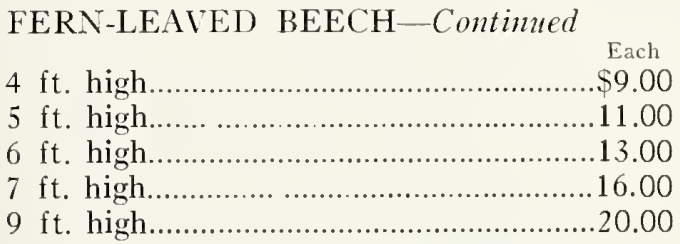

\section{EUROPEAN. Fagus Sylvatica} European Beech will be as greatly appreciated in this country as it now is in England, where it is one of the favorite trees for lawn and hedge planting. As a specimen it forms a large and majestic tree, with branches growing to the ground, in contrast to the maples, oaks and other high branched trees. For hedge planting it has no equal, making a beautiful, permanent and impenetrable barrier. The old leaves remain until they are forced off by the new ones in the spring, and it is therefore as useful as the evergreens for a screen during the winter.

2 in. cal., $9 \mathrm{ft}$. high.

$2 \mathrm{I} / 2$ in. cal., $11 \mathrm{ft}$. high. $\$ 11.00$

3 in. cal., $12 \mathrm{ft}$. high.

15.00

$3 \mathrm{I} / 2$ in. cal., $13 \mathrm{ft}$. high

20.00

4 in. cal., $14 \mathrm{ft}$. high

30.00

$4 \mathrm{I} / 2$ in. cal., $15 \mathrm{ft}$. high...................... 50.00

5 in. cal., $16 \mathrm{ft}$. high....................... 60.00

$5 \mathrm{I} / 2$ in. cal., $17 \mathrm{ft}$. high....................... 70.00

6 in. cal., $18 \mathrm{ft}$. high........................ 80.00

$6 \mathrm{I} / 2$ in. cal., $19 \mathrm{ft}$. high....................... 95.00

7 in. cal., $20 \mathrm{ft}$. high........................110.00

$7 \mathrm{I} / 2$ in. cal., $21 \mathrm{ft}$. high.......................125.00

8 in. cal., $22 \mathrm{ft}$. high.......................145.00

$8 \mathrm{I} / 2$ in. cal., $23 \mathrm{ft}$. high........................165.00

9 in. cal., $25 \mathrm{ft}$. high....................... 185.00

For hedge planting:

$10 \mathrm{ft}$. high, per 100 .

$\$ 1,000.00$

$11 \mathrm{ft}$. high, per $100 \ldots \ldots \ldots \ldots \ldots \ldots \ldots . . . . . . . .1,200.00$

$12 \mathrm{ft}$. high, per $100 \ldots \ldots \ldots \ldots \ldots \ldots \ldots . . . . . . . . . . .1,500.00$

$13 \mathrm{ft}$. high, per $100 \ldots \ldots \ldots \ldots \ldots \ldots \ldots . . . . .2,000.00$

$14 \mathrm{ft}$. high, per $100 \ldots \ldots \ldots \ldots \ldots \ldots \ldots \ldots . . . .2,800.00$

$15 \mathrm{ft}$. high, per $100 \ldots \ldots \ldots \ldots \ldots \ldots \ldots . . . . . . . .3,500.00$

These trees should be planted from three to five feet apart.

\section{FERN-LEAVED. Fagus Sylvatica Hetero- phylla}

A variety of the European Beech, with deeply cut, fern-like foliage. It is a rare specimen and is undoubtedly one of the finest lawn trees.

\section{WEEPING. Fagus Sylvatica Pendula}

The weeping variety of the European Beech. It is an unusually interesting tree and grows to large proportions with spreading branches drooping gracefully to the ground.

4 in. cal., $23 \mathrm{ft}$. high........ $\$ 50.00$

$4 \mathrm{r} / 2$ in. cal., $23 \mathrm{ft}$. high....................... 60.00

5 in cal., $24 \mathrm{ft}$. high...................... 75.00

\section{PURPLE. Fagus Purpurea}

A purple form of the European Beech. The foliage in spring is rich crimson, changing later to a deep purple. Our trees were selected in England especially for their color.

$2 \mathrm{~T} / 2$ in. cal., $10 \mathrm{ft}$. high $\$ 20.00$

3 in. cal., $12 \mathrm{ft}$. high.......................... 25.00

$3 \mathrm{~T} / 2$ in. cal., $14 \mathrm{ft}$. high........................ 35.00

4 in. cal., $16 \mathrm{ft}$. high......................... 45.00

$4 \mathrm{~T} / 2$ in. cal., $17 \mathrm{ft}$. high........................ 55.00

5 in. cal., $18 \mathrm{ft}$. high......................... 70.00

$5 \mathrm{I} / 2$ in. cal., $19 \mathrm{ft}$. high.......................... 90.00

RIVERS. Fague Purpurea Riversii Each

$2 \mathrm{I} / 2$ in. cal., $11 \mathrm{ft}$. high.........................\$20.00

3 in. cal., $14 \mathrm{ft}$. high......................... 25.00

$3 \mathrm{~T} / 2$ in. cal., $17 \mathrm{ft}$. high........................ 35.00

4 in. cal., $19 \mathrm{ft}$. high......................... 45.00

$4 \mathrm{~T} / 2$ in. cal., $21 \mathrm{ft}$. high........................ 55.00

\section{Birch-Betula}

\section{EUROPEAN CUT - LEAVED IVEEPING.}

Betula Laciniata Pendula

The most graceful of the White Birches. It has long, drooping branches, silvery bark and delicately cut foliage.

$4 \mathrm{I} / 2$ in. cal., $26 \mathrm{ft}$. high....................... $\$ 30.00$

5 in. cal., $28 \mathrm{ft}$. high........................ 40.00

$5 \mathrm{~T} / 2$ in. cal., $30 \mathrm{ft}$. high........................ 50.00

6 in. cal., 33 ft. high.......................... 60.00

$6 \mathrm{I} / 2$ in. cal., $34 \mathrm{ft}$. high.......................... 75.00

7 in. cal., $35 \mathrm{ft}$. high.......................... 90.00 


\section{EUROPEAN WHITE. Betula Alba}

Of upright habit, with very deep green leaves, which form a striking contrast to the brilliant white bark.

3 in. cal., $19 \mathrm{ft}$. high

$3 \mathrm{I} / 2$ in. cal., $21 \mathrm{ft}$. high $\$ 15.00$

4 in. cal., $22 \mathrm{ft}$. high 20.00

$4 \mathrm{~T} / 2$ in. cal., $24 \mathrm{ft}$. high 25.00

5 in. cal., $26 \mathrm{ft}$. high 30.00

$5 \mathrm{I} / 2$ in. cal., $27 \mathrm{ft}$. high 40.00

6 in. cal., $28 \mathrm{ft}$. high 50.00

$6 \frac{\mathrm{I}}{2}$ in. cal., $29 \mathrm{ft}$. high 60.00

7 in. cal., $30 \mathrm{ft}$. high 75.00

$7 \mathrm{~T} / 2$ in. cal., $31 \mathrm{ft}$. high 90.00

8 in. cal., $32 \mathrm{ft}$. high

105.00

$8 \mathrm{I} / 2$ in. cal., $33 \mathrm{ft}$. high 120.00

9 in. cal., $34 \mathrm{ft}$. high 135.00

$9 \mathrm{I} / 2$ in. cal., $34 \mathrm{ft}$. high 150.00

10 in. cal., $35 \mathrm{ft}$. high 170.00

$10^{\mathrm{T} / 2}$ in. cal., $35 \mathrm{ft}$. high

190.00

210.00

\section{PAPER BIRCH. Betula Papyrifera}

The finest of our native White Birches. It grows to be a large tree with creamy white bark.

3 in. cal., $16 \mathrm{ft}$. high

$3 \mathrm{I} / 2$ in. cal., $18 \mathrm{ft}$. high

$\$ 15.00$

4 in. cal., $20 \mathrm{ft}$. high.

$4 \mathrm{I} / 2$ in. cal., $21 \mathrm{ft}$. high

30.00

\section{Catalpa}

\section{CHINESE. Catalpa Bungei}

Used in formal gardening in place of the Bay Tree, as it has the same outline, but is hardy.

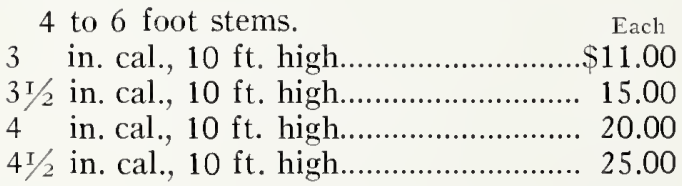

\section{WESTERN. Catalpa Speciosa}

Grows very rapidly and forms a large picturesque tree.

Each

$2^{1 / 2}$ in. cal., $11 \mathrm{ft}$. high

3 in. cal., $11 \mathrm{ft}$. high

10.00

$3 \mathrm{I} / 2$ in. cal., $12 \mathrm{ft}$. high

12.00

4 in. cal., $12 \mathrm{ft}$. high

16.00

$4 \mathrm{I} / 2$ in. cal., $12 \mathrm{ft}$. high

20.00

\section{Cercidiphyllum}

\section{JAPANESE. Cercidiphyllum Japonicum}

This is a rare and interesting tree to plant for a low screen. It grows about twenty feet high and is very symmetrical in form, with branches growing to the ground. Its greatest beauty is the foliage. In the spring the young leaves are copper-colored and in the autumn they turn to unusual shades of purplish red and yellow.

$8 \mathrm{ft}$. high.............................................. $\$ 10.00$

$9 \mathrm{ft}$. high......................................... 12.00

$10 \mathrm{ft}$. high............................................ 15.00

$11 \mathrm{ft}$. high........................................ 18.00

$12 \mathrm{ft}$. high........................................ 21.00

$13 \mathrm{ft}$. high.......................................... 25.00

$14 \mathrm{ft}$. high........................................... 30.00

$15 \mathrm{ft}$. high........................................... 40.00

$16 \mathrm{ft}$. high........................................... 50.00

$17 \mathrm{ft}$. high............................................. 65.00

$18 \mathrm{ft}$. high............................................ 80.00

\section{Dogwood-Cornus}

\section{WHITE-FLOWERING. Cornus Florida}

The most valuable of our flowering trees, being equally beautiful in the spring and fall. The large white blossoms appear in May and during the late summer and fall the berries and leaves turn a brilliant scarlet.

Each

$6 \mathrm{ft}$. high. $\$ 10.00$

$7 \mathrm{ft}$. high 12.00

$8 \mathrm{ft}$. high 15.00

$9 \mathrm{ft}$. high 20.00

$10 \mathrm{ft}$. high 30.00

$11 \mathrm{ft}$. high. 40.00

$12 \mathrm{ft}$. high 50.00

$13 \mathrm{ft}$. high 65.00

\section{RED-FLOWERING. Comus Florida Rubra}

A rare and grafted form of Dogwood, which bears rose-red blossoms. When grouped with the white-flowering variety a beautiful effect is obtained.

$4 \mathrm{ft}$. high

$5 \mathrm{ft}$. high $\$ 10.00$

$6 \mathrm{ft}$. high

12.00

$7 \mathrm{ft}$. high.

15.00

$8 \mathrm{ft}$. high. 


\section{Elm-Ulmus}

\section{AMERICAN. Ulmus Americana}

The most characteristic of our native shade trees. It forms a noble avenue, the outward curve of the branches giving the effect of a Gothic arch.

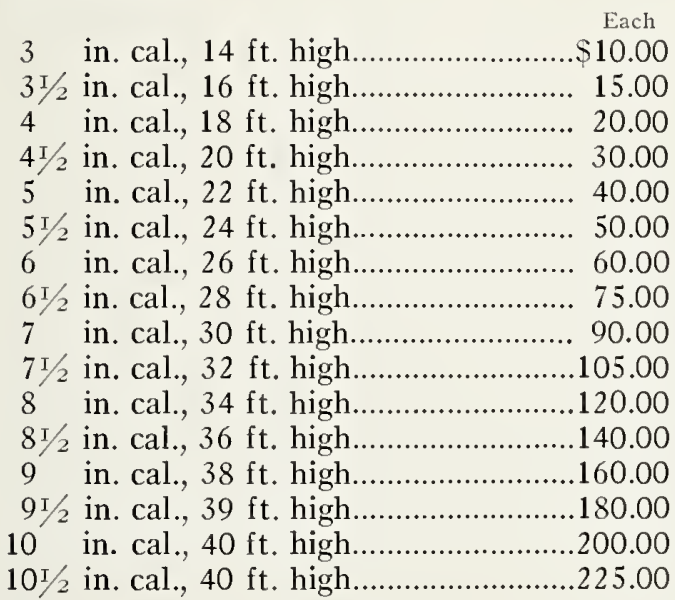

\section{EUROPEAN. Ulmus Campestris Latifolia}

A stately, compact, robust tree which holds its branches up and carries its leaves until late in the autumn. It grows rapidly and becomes a very majestic specimen.

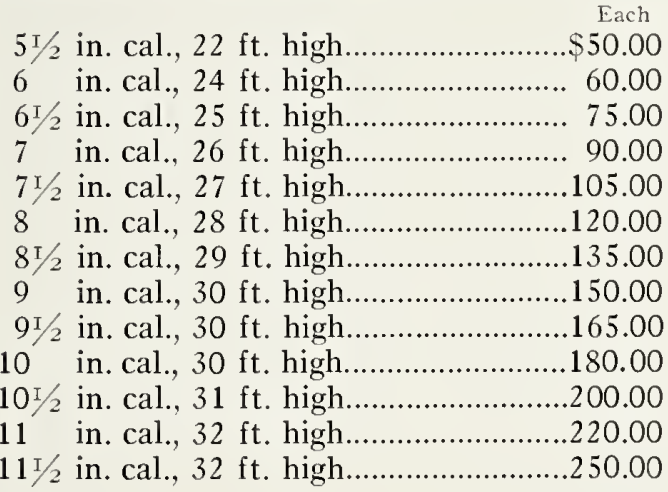

\section{Ginkgo-Salisburia}

\section{MAIDENHAIR TREE.}

\section{Salisburia Adiantifolia}

This tree has become very popular during the last few years, owing to its unusual form and its odd leaves which resemble those of

\section{MAIDENHAIR GINKGO-Continued}

the maidenhair fern. It is especially to be recommended for city planting.

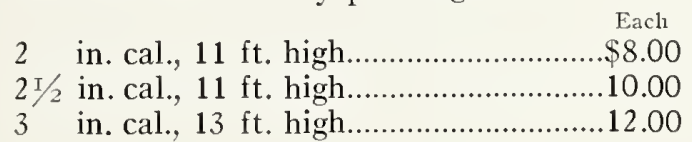

\section{Hawthorn-Crataegus}

\section{COCKSPUR-Crataegus Crus-Galli}

Forms a bushy tree about ten feet high, with clusters of bright red fruit in the autumn.

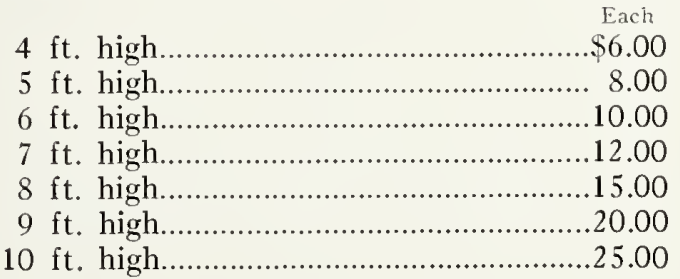

\section{ENGLISH. Crataegus Oxycantha}

The white blossomed Hawthorn of the English hedgerows.

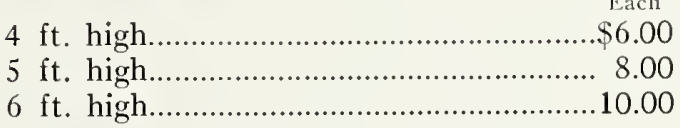

\section{PAUL'S SCARLET. Crataegus Coccinea}

A beautiful variety of Hawthorn which bears red flowers.

$5 \mathrm{ft}$. high.

$6 \mathrm{ft}$. high.

\section{Horsechestnut-Aesculus}

\section{WHITE DOUBLE-FLOWERING}

Aesculus Hippocastanum Flore Albo Pleno

The finest variety of Horsechestnut. It has double flowers and bears no nuts and hence is best for park and avenue planting.

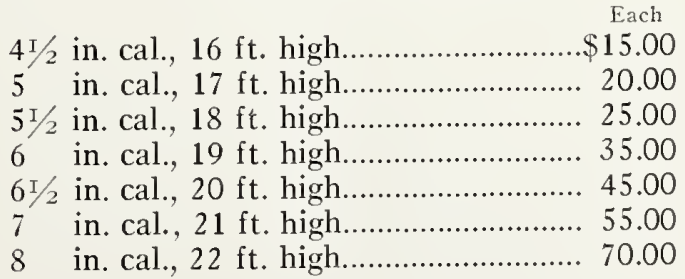




\section{Linden-Tilia}

\section{AMERICAN. Tilia Americana}

A handsome native shade tree which grows very quickly and thrives in the poorest soil. It forms a very symmetrical avenue tree. The fragrant white flowers appear in June.

$4^{\mathrm{T}} / 2$ in. cal., $21 \mathrm{ft}$. high

5 in. cal., 22 ft. high. $\$ 15.00$

$5 \mathrm{~T} / 2$ in. cal., $23 \mathrm{ft}$. high. 20.00

6 in. cal., $24 \mathrm{ft}$. high.

25.00

$6 \mathrm{~T} / 2 \mathrm{in}$. cal., $25 \mathrm{ft}$. high.

35.00

7 in. cal., $26 \mathrm{ft}$. high.

45.00

$7 \mathrm{I} / 2$ in. cal., $27 \mathrm{ft}$. high.

55.00

70.00

\section{CRIMEAN. Tilia Dasystyla}

This variety is notable for its glossy green foliage, which retains its freshness until late in the fall. The twigs are a bright yellow.

3 in. cal., $14 \mathrm{ft}$. high

Each

$3 \mathrm{~T} / 2$ in. cal., $15 \mathrm{ft}$. high

$\$ 12.00$

\section{EUROPEAN LARGE-LEAVED.}

\section{Tilia Platyphyllos}

The broad-leaved variety, which forms the largest tree of all the Lindens.

3 in. cal., $18 \mathrm{ft}$. high.

$3 \mathrm{~T} / 2$ in. cal., $20 \mathrm{ft}$. high.

$\$ 12.00$

4 in. cal., $21 \mathrm{ft}$. high

15.00

$4 \mathrm{I} / 2$ in. cal., $24 \mathrm{ft}$. high

20.00

5 in. cal., $26 \mathrm{ft}$. high

$51 / 2$ in. cal., $28 \mathrm{ft}$. high

40.00

6 in. cal., $30 \mathrm{ft}$. high

50.00

60.00

\section{EUROPEAN SMALL-LEAVED.}

\section{Tilia Vulgaris}

The best Linden for street planting. It grows rapidly and holds its leaves until very late in the autumn.

3 in. cal., $14 \mathrm{ft}$. high.

$3 \mathrm{I} / 2$ in. cal., $16 \mathrm{ft}$. high.

$\$ 12.00$

4 in. cal., $18 \mathrm{ft}$. high

15.00

$4 \mathrm{I} / 2$ in. cal., $19 \mathrm{ft}$. high

20.00

5 in. cal., $20 \mathrm{ft}$. high

30.00

$5 \mathrm{I} / 2$ in. cal., $21 \mathrm{ft}$. high

40.00

6 in. cal., $22 \mathrm{ft}$. high

50.00

60.00

\section{SILVER. Tilia Argentea.}

An unusually symmetrical tree with very luxuriant foliage. The leaves are dark green above and silver on the under side.

4 in. cal., $18 \mathrm{ft}$. high

\section{SILVER LINDEN-Continued}

5 in. cal., $22 \mathrm{ft}$. high.

$5 \mathrm{~T} / 2$ in. cal., $23 \mathrm{ft}$. high.

$\$ 35.00$

6 in. cal., $23 \mathrm{ft}$. high.

45.00

$6 \mathrm{~T} / 2$ in. cal., $23 \mathrm{ft}$. high.

55.00

7 in. cal., $24 \mathrm{ft}$. high.

65.00

$7 \mathrm{I} / 2$ in. cal., $24 \mathrm{ft}$. high.

75.00

8 in. cal., $24 \mathrm{ft}$. high.

85.00

$8 \mathrm{~T} / 2$ in. cal., $25 \mathrm{ft}$. high.

100.00

\section{Maple-Acer}

\section{NORWAY. Acer Platanoides}

The Norway Maple is one of the most satisfactory trees for either street or lawn planting. It grows rapidly in even the poorest soil and most exposed situations and suffers practically no setback after transplanting. It forms a large tree with a spreading head and deep green leaves, which remain on the tree until November. The only condition in which the Norway Maple will not thrive is in very wet ground. There it is safer to plant the Sugar or Silver Maple.

The Amawalk Nursery contains many thousand specimen Norway Maples from two to nine-inch caliper, the finest stock of these trees in this country.

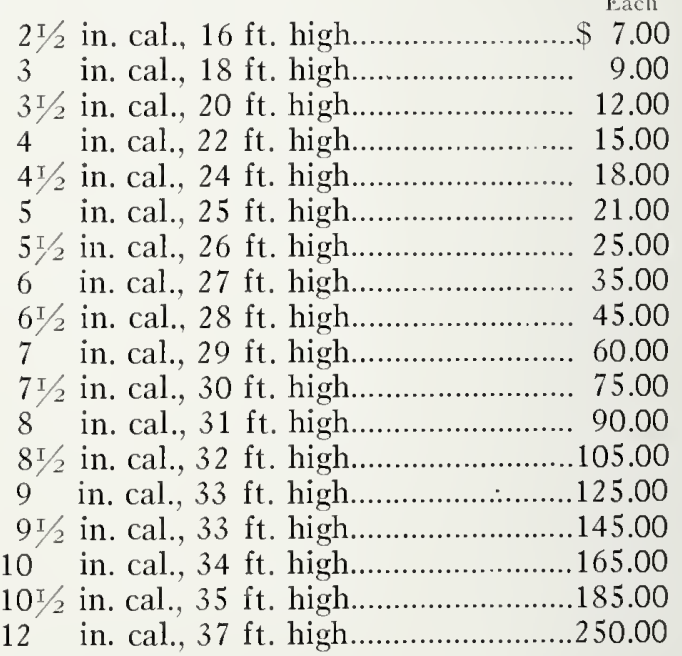

\section{GLOBE-HEADED NORIVAY Acer Platanoides Globosum}

An unusual grafted form of Norway Maple. These are splendid specimens with dense, round heads of very compact growth. They are very effective in formal planting as a substitute for the more common Catalpa Bungeii. 


\begin{tabular}{lllll}
\hline कु & A M A W A L K N U R S E R Y & ध \\
\hline
\end{tabular}

\section{GLOBE-HEADED MAPLE-Continued}

4 to 7 foot stems. Eacli 4 in. cal., $12 \mathrm{ft}$. spread.......................\$40.00 $4 \mathrm{I} / 2$ in. cal., $13 \mathrm{ft}$. spread..................... 50.00

5 in. cal., $14 \mathrm{ft}$. spread...................... 60.00 $5 \mathrm{I} / 2$ in. cal., $15 \mathrm{ft}$. spread..................... 75.00

\section{SCHWEDLER'S NORWAY.}

Acer Platanoides Schwedleri

A variety of the Norway Maple with very brilliant coloring. The foliage in the spring is blood-red, turning later to a rich, very dark green.

Each

$2 \mathrm{~T} / 2$ in. cal., $13 \mathrm{ft}$. high.

8.00

3 in. cal., $14 \mathrm{ft}$. high.

10.00

$3 \mathrm{I} / 2$ in. cal., $15 \mathrm{ft}$. high.

13.00

4 in. cal., $16 \mathrm{ft}$. high.

16.00

$4 \mathrm{~T} / 2$ in. cal., $17 \mathrm{ft}$. high.

20.00

5 in. cal., $18 \mathrm{ft}$. high.

25.00

$51 / 2$ in. cal., $19 \mathrm{ft}$. high.

30.00

6 in. cal., $20 \mathrm{ft}$. high.

40.00

$61 / 2$ in. cal., $21 \mathrm{ft}$. high.

50.00

7 in. cal., $22 \mathrm{ft}$. high.

65.00

$71 / 2$ in. cal., $23 \mathrm{ft}$. high.

80.00

8 in. cal., $24 \mathrm{ft}$. high.

95.00

$81 / 2$ in. cal., $25 \mathrm{ft}$. high.

110.00

\section{SCARLET. Acer Rubrum}

Remarkable in the spring for its masses of red flowers and seeds, and in the fall for its brilliant crimson leaves.

$41 / 2$ in. cal., $20 \mathrm{ft}$. high. Each

5 in. cal., $21 \mathrm{ft}$. high. $\$ 20.00$

$5 \mathrm{~T} / 2$ in. cal., $21 \mathrm{ft}$. high.

30.00

6 in. cal., $22 \mathrm{ft}$. high. 40.00

$6 \mathrm{I} / 2$ in. cal., $23 \mathrm{ft}$. high. 50.00

7 in. cal., $24 \mathrm{ft}$. high. 60.00

8 in. cal., $25 \mathrm{ft}$. high. 75.00

9 in. cal., $26 \mathrm{ft}$. high.

105.00

135.00

\section{SUGAR. Acer Saccharum}

A well-known native shade tree which thrives in moist ground. It is one of the finest trees for fall coloring, the foliage turning to shades of yellow, orange and scarlet.

$2 \mathrm{I} / 2$ in. cal., $18 \mathrm{ft}$. high Each

3 in. cal., $20 \mathrm{ft}$. high $\$ 8.00$

$3 \mathrm{~T} / 2$ in. cal., $22 \mathrm{ft}$. high 10.00

4 in. cal., $24 \mathrm{ft}$. high 12.00

$4 \mathrm{I} / 2$ in. cal., $26 \mathrm{ft}$. high 15.00

5 in. cal., $28 \mathrm{ft}$. high 20.00

$5 \mathrm{I} / 2$ in. cal., $29 \mathrm{ft}$. high 30.00

6 in. cal., $30 \mathrm{ft}$. high 40.00

$61 / 2$ in. cal., $31 \mathrm{ft}$. high

50.00

7 in. cal, $32 \mathrm{ft}$. high 65.00

$71 / 2$ in. cal., $33 \mathrm{ft}$. high 80.00

8 in. cal., $34 \mathrm{ft}$. high 95.00

$81 / 2$ in. cal., $35 \mathrm{ft}$. high
PYRAMIDAL SILVER.

\section{Acer Dasycarpum Pyramidalis}

The best tree to plant where a rapid grower is desired for immediate effect. It is a new and superior variety of the Silver Maple, of compact, symmetrical form and remarkably. quick growth.

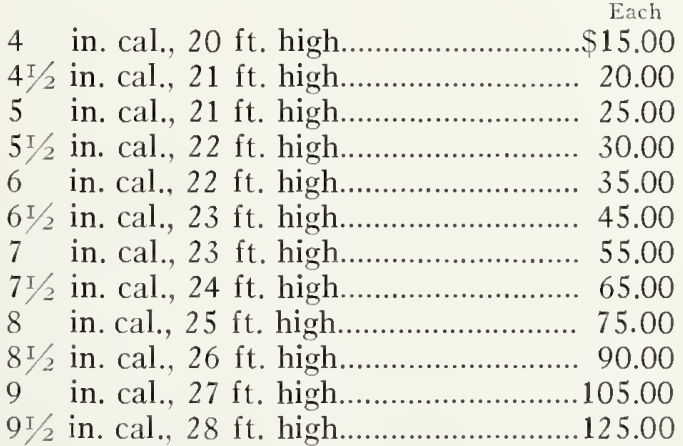

PURPLE-LEAVED SYCAMORE.

\section{Acer Psendo-Platanus Atropurpureum}

A very fine lawn tree with remarkably beautiful foliage. The leaves are a rich, dark green above, and deep, purplish red on the under side, and retain this coloring until fall, when the red becomes more brilliant and the green turns to clear yellow.

\begin{tabular}{|c|c|}
\hline $4 \frac{1}{2}$ in. cal., $20 \mathrm{ft}$. high.. & \\
\hline 5 in. cal., $21 \mathrm{ft}$. high.... & 30.00 \\
\hline $51 / 2$ in. cal., $22 \mathrm{ft}$. high.... & 40.0 \\
\hline 6 in. cal., $23 \mathrm{ft}$. high... & 50.00 \\
\hline$/ 2$ in. cal., $24 \mathrm{ft}$. high..... & 60.0 \\
\hline in. cal., $25 \mathrm{ft}$. high..... & \\
\hline 1. cal., $26 \mathrm{ft}$. high... & \\
\hline 1. cal., $27 \mathrm{ft}$. high.... & \\
\hline
\end{tabular}

\section{Japanese Maple-Acer Palmatum}

The Japanese Maple forms a small low branched tree, growing not more than twenty feet high. It is very extensively used for its brilliant coloring and is most effective when several specimens are massed together.

\section{DARK PURPLE-LEAVED.}

\section{Acer Palmatum Atropurpureum}

The leaves of this variety are blood-red in the spring, turning to a rich purple which lasts throughout the summer. 


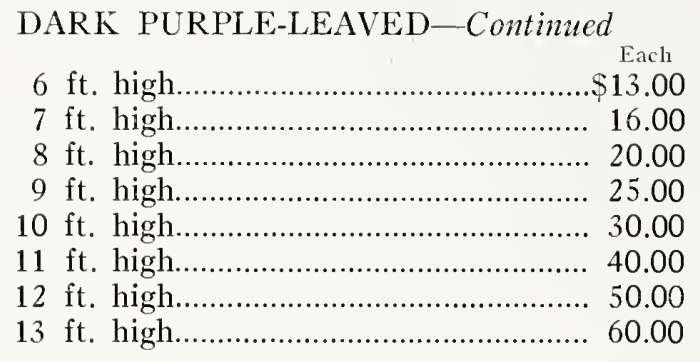

OSAKAZUKI. Acer Palmatum Osakazuki

The best variety to plant for fall coloring. The leaves are green in the summer and become bright red in the autumn.

\begin{tabular}{|c|c|}
\hline $6 \mathrm{ft}$. high. & $\begin{array}{c}\text { Each } \\
. \$ 13.00\end{array}$ \\
\hline $7 \mathrm{ft}$. high. & 16.0 \\
\hline $8 \mathrm{ft}$. high. & 20.0 \\
\hline $9 \mathrm{ft}$. high. & 25.0 \\
\hline high & 30.0 \\
\hline hiot & 40.0 \\
\hline & 50. \\
\hline
\end{tabular}

\section{Mountain Ash-Sorbus}

\section{EUROPEAN. Sorbus Aucuparia}

A small tree, conspicuous in the fall for its clusters of red berries.

2 in. cal., $10 \mathrm{ft}$. high

$2 \mathrm{~T} / 2$ in. cal., $11 \mathrm{ft}$. high

3 in. cal., $12 \mathrm{ft}$, high 15.00

\section{Nettle Tree-Celtis}

\section{Celtis Occidentalis}

An unusually hard native tree, which will withstand the most adverse conditions. It grows with a wide-spreading head, and is especially to be recommended for planting in dry ground.

$2 \mathrm{r} / 2$ in. cal., $11 \mathrm{ft}$. high

3 in. cal., $13 \mathrm{ft}$. high

$3 \mathrm{I} / 2$ in. cal., $14 \mathrm{ft}$. high

10.00

4 in. cal., $15 \mathrm{ft}$. high.

20.00

\section{Oak-Quercus}

It is generally considered that the Oaks are of very slow growth, and for that reason they are not planted as extensively as their beauty and vigor merit. This is a mistaken idea. The Oaks here catalogued make nearly as rapid a growth as, for example, the Sugar Maple.

\section{AMERICAN PIN. Quercus Palustris}

The most rapid growing of the Oaks. It is a very beautiful variety, distinguished by its long, somewhat drooping branches. The foliage is deeply cut and turns orange and scarlet in the fall.

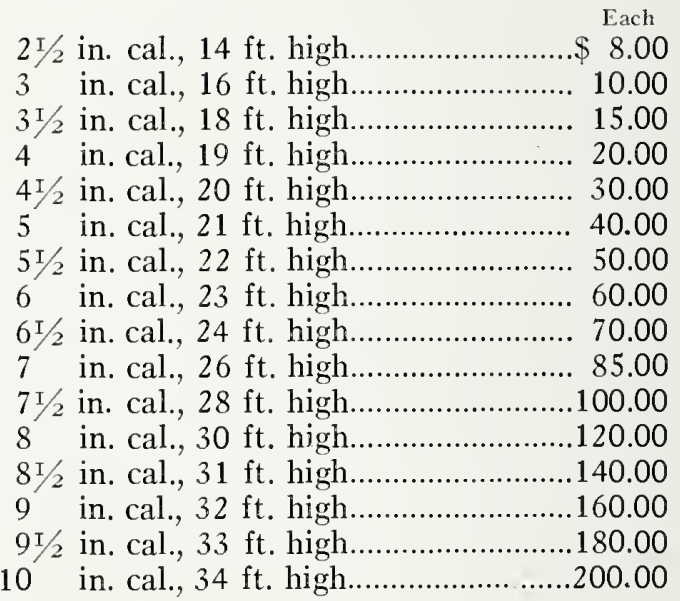

\section{AMERICAN RED. Quercus Rubra}

Of vigorous, upright habit. The leaves are very large, of a rich, dark green, changing to deep red in the autumn.

$2 \mathrm{~T} / 2$ in. cal., $14 \mathrm{ft}$. high......................... $\$ 8.00$

3 in. cal., $18 \mathrm{ft}$. high........................ 10.00

$3 \mathrm{r} / 2$ in. cal., $20 \mathrm{ft}$. high.......................... 15.00

4 in. cal., $22 \mathrm{ft}$. high.......................... 20.00

$4 \mathrm{I} / 2$ in. cal., $24 \mathrm{ft}$. high.......................... 30.00

5 in. cal., $25 \mathrm{ft}$. high......................... 40.00

$5 \mathrm{r} / 2$ in. cal., $26 \mathrm{ft}$. high........................ 50.00

6 in. cal., 27 ft. high........................ 60.00

$6 \mathrm{I} / 2$ in. cal., $28 \mathrm{ft}$. high........................ 70.00

7 in. cal., $29 \mathrm{ft}$. high........................ 85.00

$7 \mathrm{r} / 2$ in. cal., $29 \mathrm{ft}$. high............................100.00

8 in. cal., $30 \mathrm{ft}$. high.........................120.00

\section{ENGLISH. Quercus Robur Pedunculata}

Forms a large tree with spreading branches and a broad round-topped head.

$3 \mathrm{I} / 2$ in. cal., $20 \mathrm{ft}$. high Each

$\$ 15.00$

5 in cal, $24 \mathrm{ft}$. high.................... 20.00

5 in. cal., $24 \mathrm{ft}$. high........................ 40.00

6 in. cal., $26 \mathrm{ft}$. high......................... 60.00

$6 \mathrm{~T} / 2 \mathrm{in}$. cal., $27 \mathrm{ft}$. high......................... 70.00 


\section{Poplar-Populus}

\section{LOMBARDY. Populus Nigra Fastigiata}

A very quick growing tree, used in landscape work for its narrow pyramidal form.

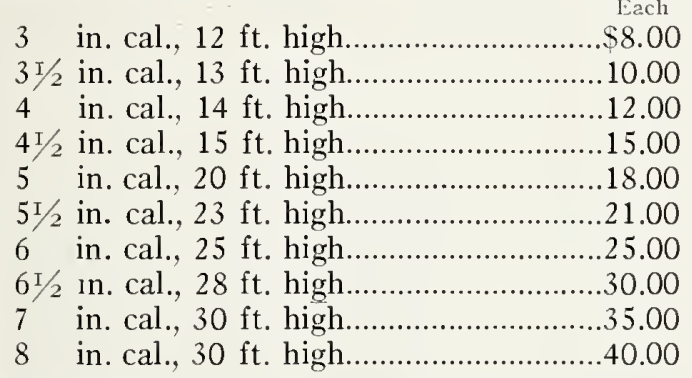

\section{Sweet Gum-Liquidambar}

\section{Liquidambar Styraciflua}

A splendid ornamental tree of symmetrical growth. It has glossy star-shaped green leaves, which turn to brilliant crimson hues in the autumn.

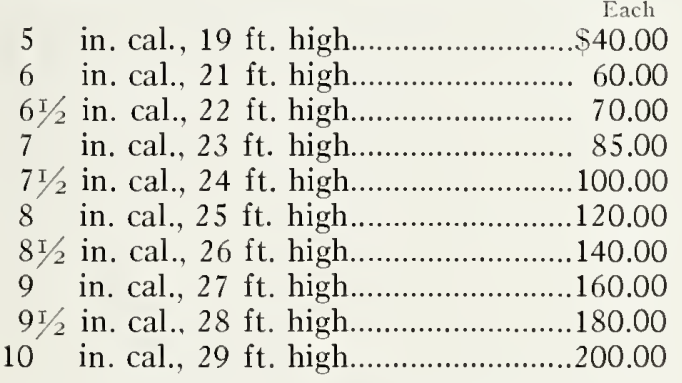

\section{Tulip Tree-Liriodendron}

\section{Liriodendron Tulipifera}

A native forest tree of tall, pyramidal habit. It has light green, glossy foliage, and tulipshade flowers.

3 in. cal., $18 \mathrm{ft}$. high Each $3 \mathrm{~T} / 2$ in. cal., $18 \mathrm{ft}$. high 4 in. cal., $19 \mathrm{ft}$. high $\$ 10.00$

$4 \mathrm{I} / 2$ in. cal., $19 \mathrm{ft}$. high........................ 30.00

5 in. cal., $20 \mathrm{ft}$. high.......................... 40.00

$5 \mathrm{I} / 2$ in. cal., $20 \mathrm{ft}$. high........................ 50.00

6 in. cal., 21 ft. high.......................... 60.00

$6 \mathrm{r} / 2$ in. cal., $21 \mathrm{ft}$. high............................. 70.00

7 in. cal., $22 \mathrm{ft}$. high......................... 85.00

$7 \mathrm{I} / 2$ in. cal., $22 \mathrm{ft}$. high...........................100.00

8 in. cal., 23 ft. high..........................120.00

$8 \mathrm{r} / 2$ in. cal., $23 \mathrm{ft}$. high...........................140.00

9 in. cal., 24 ft. high............................160.00

\section{Willow-Salix}

The willows are among the most satisfactory trees to plant in very wet ground, where they make rapid growth.

\section{LAUREL-LEAVED. Salix Pentandra}

A small upright tree with shining, dark, green leaves.

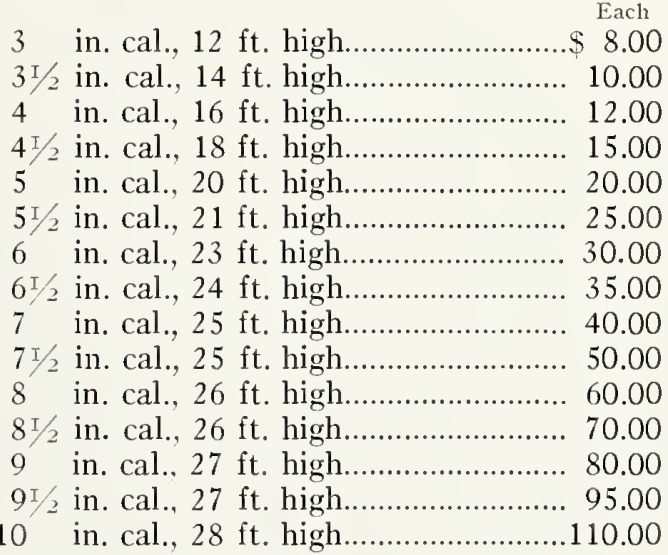

\section{SALMION BARKED.}

\section{Salix Vitellina Britzensis}

The bark is salmon colored and very conspicuous in winter when it turns a golden red.

3 in. cal., $12 \mathrm{ft}$. high....................... $\$ 8.00$

$3 \mathrm{I} / 2$ in. cal., $13 \mathrm{ft}$. high...........................10.00

4 in. cal., $14 \mathrm{ft}$. high...........................12.00

\section{THURLOW'S. Salix Elegantissima}

This variety grows in symmetrical form, with a straight trunk and drooping branches.

$3 \mathrm{~T} / 2$ in. cal., $16 \mathrm{ft}$. high........................ $\$ 10.00$

4 in. cal., $17 \mathrm{ft}$. high......................... 12.00

$4 \mathrm{~T} / 2$ in. cal., $18 \mathrm{ft}$. high........................ 15.00

5 in. cal., $19 \mathrm{ft}$. high........................ 20.00

$5^{\mathrm{T} / 2}$ in. cal., $20 \mathrm{ft}$. high.......................... 25.00

6 in. cal., $21 \mathrm{ft}$. high......................... 30.00

$6 \mathrm{~T} / 2$ in. cal., $22 \mathrm{ft}$. high........................ 35.00

\section{IVEEPING. Salix Babylonica}

The well-known Weeping Willow. These trees grow in picturesque, irregular forms, with spreading branches.

$3 \mathrm{I} / 2$ in cal $16 \mathrm{ft}$ high Each

4 in. cal., $17 \mathrm{ft}$. high........................ 12.00

$4 \mathrm{~T} / 2$ in. cal., $18 \mathrm{ft}$. high....................... 15.00

5 in. cal., 19 ft. high....................... 20.00

$5 \mathrm{~T} / 2$ in. cal., $20 \mathrm{ft}$. high....................... 25.00

6 in. cal., $20 \mathrm{ft}$. high........................ 30.00 


\begin{tabular}{lllll}
\hline \multirow{2}{*}{ A M A W A L K } & N U R S E R Y & O \\
\hline \hline
\end{tabular}

\section{Conifers}

Namely, the cone-bearing trees, but generally understood

to refer to the evergreens

\section{Arborvitae-Thuya}

\section{AMERICAN. Thuya Occidentalis}

A native evergreen of pyramidal growth especially adapted for hedges and formal planting.

Each

$5 \mathrm{ft} . \mathrm{high}$

$6 \mathrm{ft}$ high........................................ 7.00

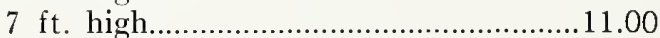

$8 \mathrm{ft}$. high................................................ 13.00

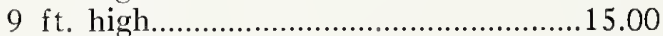

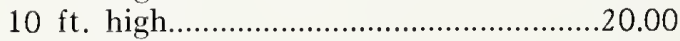

$11 \mathrm{ft}$. high............................................25.00

$12 \mathrm{ft}$. high..................................................30.00

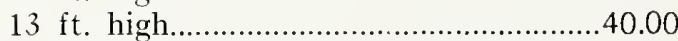

$14 \mathrm{ft}$. high...............................................50.00

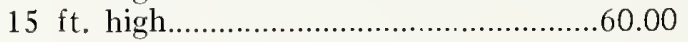

\section{GLOBE. Thuya Globosum}

A dwarf, globe-shaped variety, useful for planting in borders.

2 ft. high.

Each

$2 \mathrm{I} / 2 \mathrm{ft}$. high.

$\$ 6.00$

8.00

\section{SIBERIAN. Thuya Occidentalis Wareana}

A very hardy variety of compact growth and dark green coloring.

$3 \mathrm{ft}$. high

Each

$4 \mathrm{ft}$. high

$\$ 7.00$

9.00

\section{Cryptomeria}

\section{Cryptomeria Lobbi Compacta}

A distinctive rapid growing Japanese evergreen, having light green foliage which assumes a brownish tinge in the autumn.

$6 \mathrm{ft}$. high

Each

$7 \mathrm{ft}$. high

$8 \mathrm{ft}$. high

15.00

\section{Hemlock_Tsuga}

HEMLOCK SPRUCE. Tsuga Canadensis

A graceful and beautiful evergreen. Very ornamental when planted singly, and as it stands close shearing it also forms a splendid hedge. It is the only evergreen that can be grown in a partial shade.

We can supply Hemlocks in the following sizes, either closely sheared for formal effects and hedge planting, or with their natural open growth.

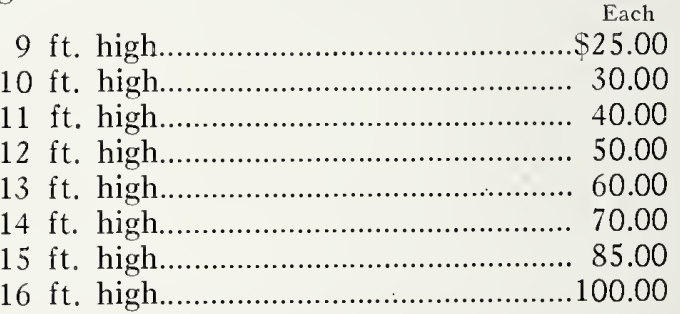

\section{Juniper-Juniperus}

PFITZER'S. Juniperus Pfitzeriana

A low-growing form of Juniper, with spreading branches. The foliage is bluish green.

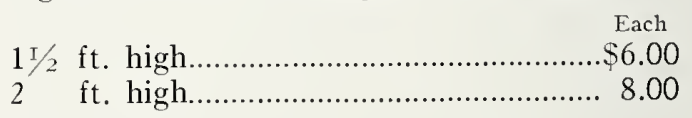

\section{RED CEDAR. Juniperus Virginiana}

Our native Red Cedar, which will grow on the dryest hillside. Its narrow, pyramidal shape makes it valuable in landscape work.

\begin{tabular}{|c|c|}
\hline & $\begin{array}{c}\text { Each } \\
. \$ 6.00\end{array}$ \\
\hline $5 \mathrm{ft}$. high. & .. 8.00 \\
\hline $6 \mathrm{ft}$. high.. & .10 .00 \\
\hline $7 \mathrm{ft}$. high.. &. .12 .00 \\
\hline t. high... &. .15 .00 \\
\hline . high.. & 20.00 \\
\hline
\end{tabular}


BLUE CEDAR.

\section{Juniperus Virginiana Glauca}

Similar to the Red Cedar, but of an unusually beautiful violet blue color.

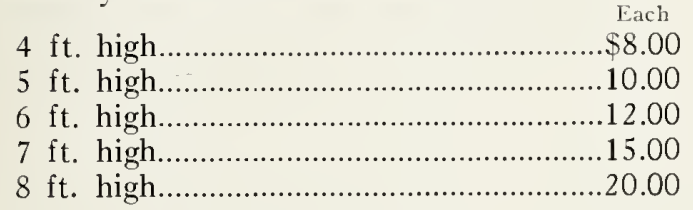

\section{SAVIN. Juniperus Sabina}

Deep green foliage and spreading form. Very valuable for planting in front of taller evergreens and for use as a border.

$1 \mathrm{I} / 2 \mathrm{ft}$. high.

Each

STRICTA. Excelsa Stricta

Upright, pyramidal form, with bluish green foliage.

$2 \mathrm{ft}$. high...

Each $\$ 8.00$

\section{Larch-Larix}

\section{JAPANESE. Larix Kaempferi}

This is the finest species of Larch and very rare. The foliage turns to a rich shade of burnt orange in the autumn.

$12 \mathrm{ft}$. high Each

13 ft. high $\$ 20.00$

$14 \mathrm{ft}$. high 30.00

$15 \mathrm{ft}$. high 40.00

$16 \mathrm{ft}$. high 50.00

$17 \mathrm{ft}$. high 60.00

$18 \mathrm{ft}$. high

70.00 80.00

\section{Pine-Pinus}

\section{AUSTRIAN. Pinus Austriaca}

The hardiest evergreen grown. It thrives in the most exposed situations and is adapted to any soil except very wet ground. It forms a stately and symmetrical tree with spreading branches and rich, dark green needles.

$10 \mathrm{ft}$. high Each

$11 \mathrm{ft}$. high $\$ 30.00$

$12 \mathrm{ft}$. high

35.00

$13 \mathrm{ft}$. high

40.00

$14 \mathrm{ft}$. high

50.00

15 ft. high

60.00

$16 \mathrm{ft}$. high

70.00

$17 \mathrm{ft}$. high

\section{AUSTRIAN PINE-Continued}

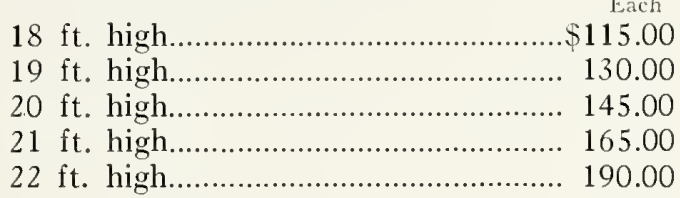

\section{CORSICAN. Pinus Laricio Corsica}

An interesting variety, with long, twisted needles.

Each

$3 \mathrm{ft}$. high................................................ $\$ 6.00$

$4 \mathrm{ft}$. high............................................ 7.00

$5 \mathrm{ft}$. high.............................................. 8.00

\section{MUGHO. Pinus Mughus}

A dwarf variety, with dark green foliage, suitable for growing in evergreen groups and rockeries.

Each

1 ft. high.......................................... $\$ 5.00$

$1 \mathrm{r} / 2 \mathrm{ft}$. high........................................ 6.00

2 ft. high........................................ 8.00

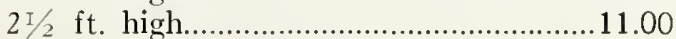

\section{SCOTCH. Pinus Sylvestris}

A hardy variety of Pine adapted to dry soil. It grows rapidly, and has short bluish green needles.

$5 \mathrm{ft}$. high.

$6 \mathrm{ft}$. high.

$7 \mathrm{ft}$. high

12.00

$8 \mathrm{ft}$. high

.

$9 \mathrm{ft}$. high.

25.00

\section{WHITE. Pinus Strobus}

A popular variety of Pine. It grows rapidly and has soft, light green needles.

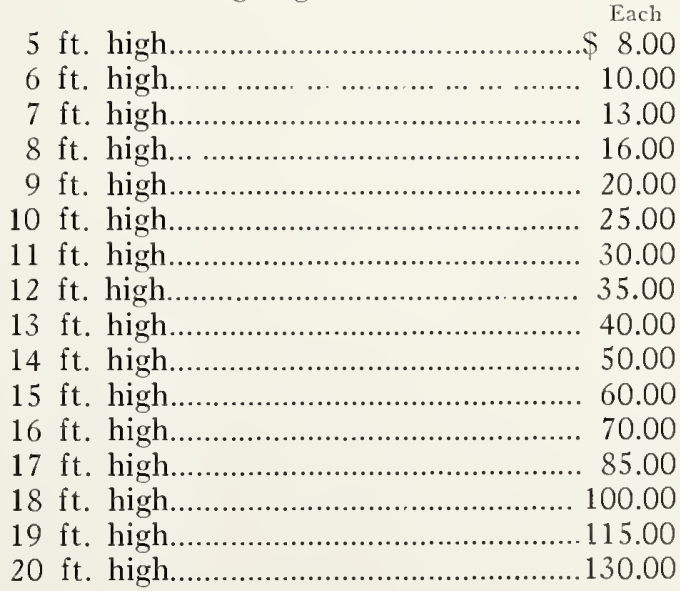




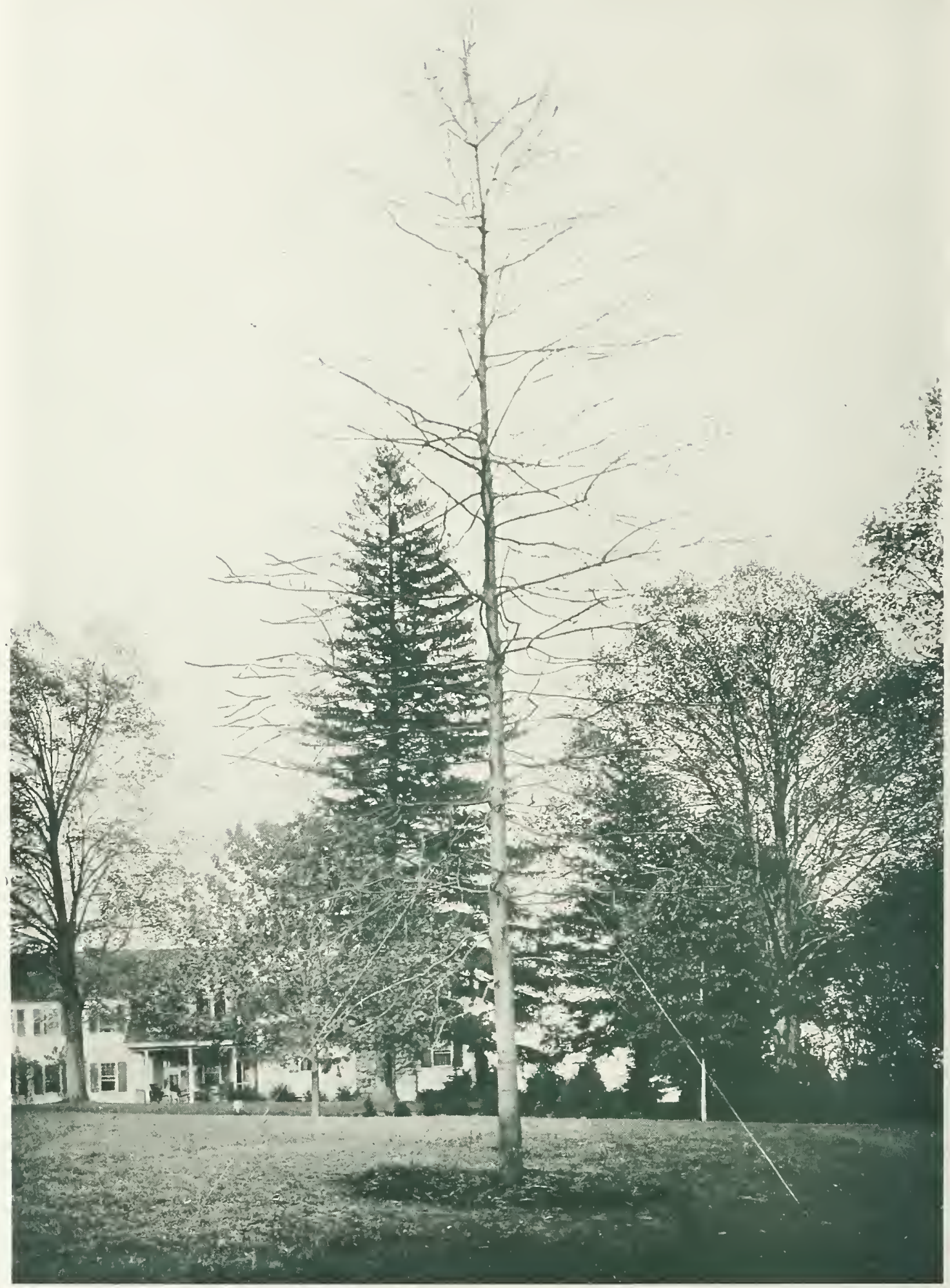

A tree properly planted sustained by guy wires. 


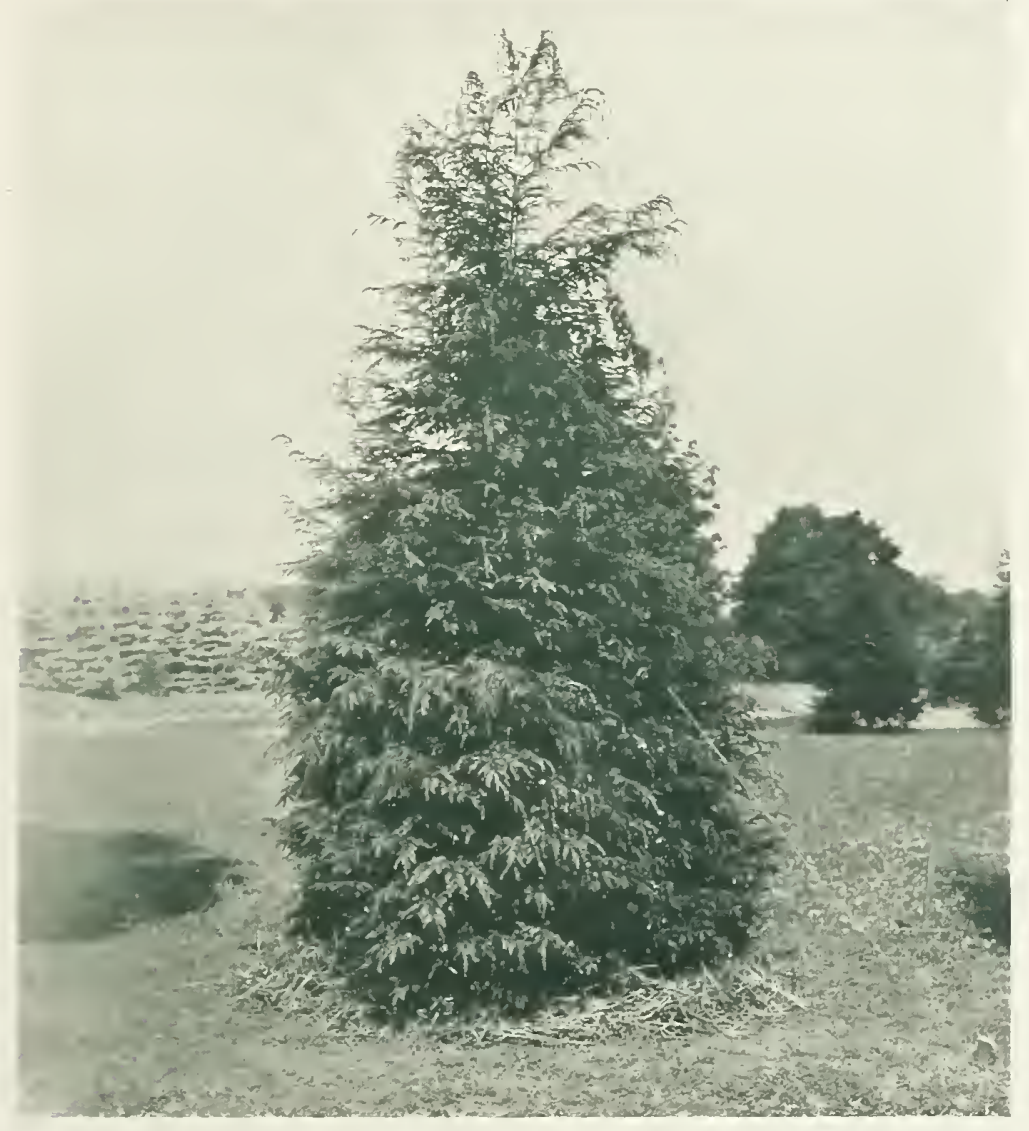

\section{Instructions for Planting}

All trees may be transplanted in the spring, from the time the frost is out of the ground until the new growth is far advanced. In the locality of Amawalk, deciduous trees can usually be transplanted from the end of March until the middle of May, and evergreens until the first of June.

Evergreens can again be transplanted during August and September, as their roots make a second growth at that time.

The fall planting season occurs when the trees become dormant, usually about the end of October, and lasts until about the first of December when the ground freezes. All evergreens and most deciduous trees can be planted at that time.

The more tender varieties of evergreens should be protected during the first winter. All of the deciduous trees listed in our catalogue may be transplanted in the fall except the Birches, Silver Maples, Scarlet Maples and Tulips.

All trees should be planted as soon as received. It is very important that the roots should not dry out by exposure to air or heat.

Evergreens and some varieties of deciduous trees are shipped with a ball of earth burlapped around their roots, which should be kept moist until the tree is planted.

Great care should be taken in planting. 


\section{ช}

The holes for the trees should be large enough to allow the roots to spread out to their fullest extent. Trees must be planted at the exact depth at which they grew. This is shown by the mark of the soil around the trunk.

If the ground is not fertile, good soil should be secured to fill in the holes. When this is not necessary, the top soil, being richer than the sub-soil, should be put in first. The dirt in the hole must be firmly packed down, so that the tree will not work loose.

When trees are planted in exposed situations they must be guyed to hold them firmly in place until their roots become established.

Trees need to be thoroughly watered when planted, and regularly thereafter. Once or twice a week is often enough, but plenty of water should be used.

It is well to remember that the roots of trees are comparatively deep in the ground, differing from plants, and the whole root area must be thoroughly soaked with water to insure successful planting.

If the planting is done in dry ground, only sufficient earth should be put in the hole to cover the roots. Then water should be poured in and the soaked earth allowed to settle before the hole is filled up. This particularly applies to evergreens.

Cultivation of the ground around the trees after they are planted is very important. The soil should be worked with a hoe at least once a week to keep the ground from becoming hard. This allows air and moisture to reach the roots.

The Amawalk Nursery has prepared an illustrated booklet giving detailed instructions in the planting and after care of trees. This booklet is sent to each customer before their order is shipped, and will be forwarded to any one upon request.

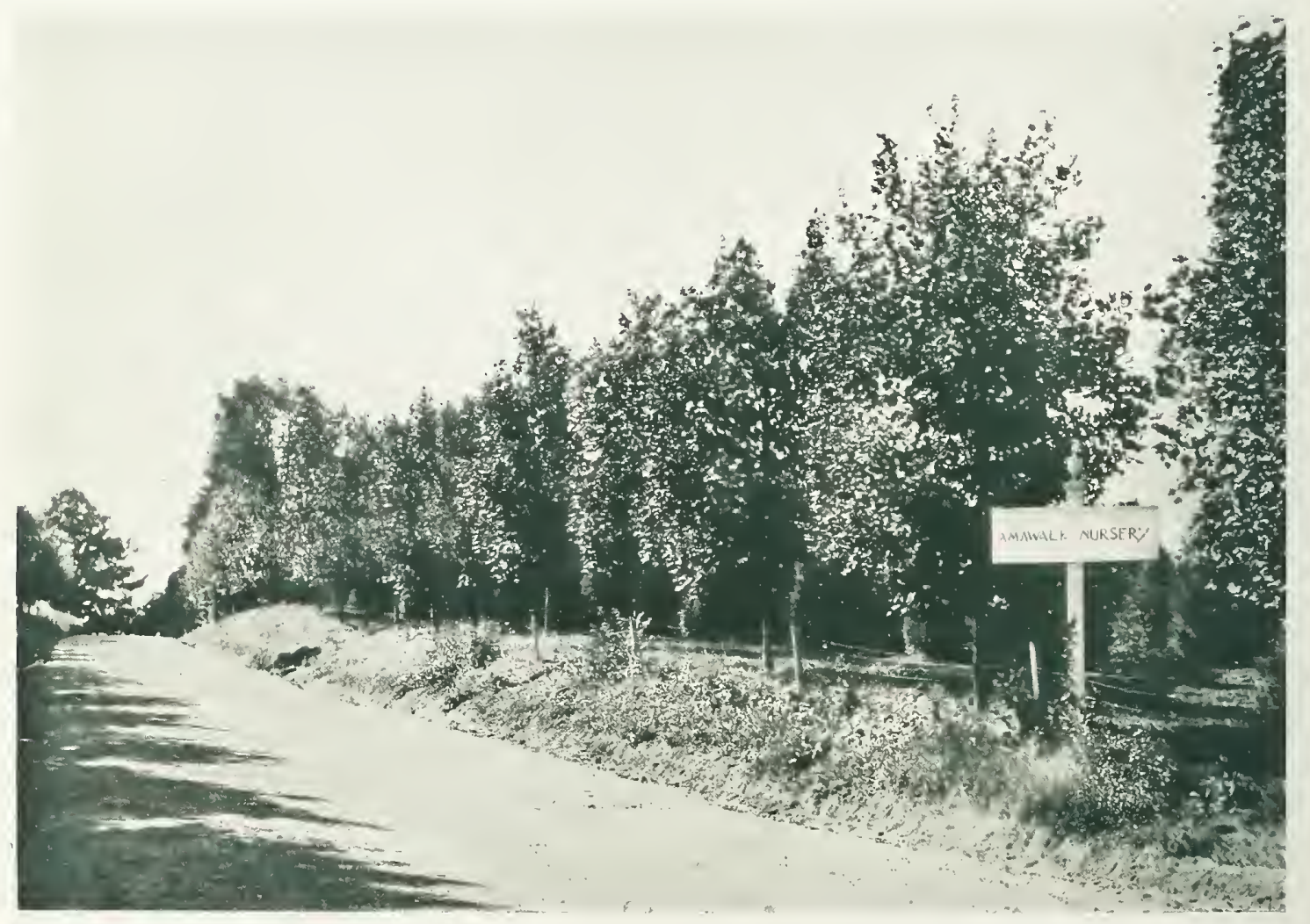



